\title{
Enhancing Growth, Productivity, Fruit Quality and Postharvest Storability of Hot Pepper by Calcium Nitrate and Salicylic Acid Foliar Application
}

\author{
Shimaa M. Hassan $^{1}{ }^{1}$, Zainab A. Abd Alhafez ${ }^{2}$, Yehia S. Mostafa ${ }^{3}$
}

\begin{abstract}
Two-year field experiments were conducted at the Agricultural Research Station, Faculty of Agriculture Alexandria University, during the two successive summer growing seasons of 2016 and 2017. The main aim was to study the influence of foliar application of calcium nitrate $\left(\mathrm{CaNO}_{3}\right)_{2}$ at $\left(0,2.5\right.$, or $\left.5 \mathrm{gl}^{-1}\right)$ and salicylic acid $(\mathrm{SA})$ at $(0$, 0.25 or $\left.0.5 \mathrm{gl}^{-1}\right)$ as well as their interactions on growth, yield and postharvest storability of Omega F1 hot pepper plants grown in clay loam soil. Harvested fruits were used for quality measurements at harvest and postharvest storability parameters after cold storage for 3 weeks at $6 \pm 1{ }^{\circ} \mathrm{C}$ and $90 \pm 5 \% \mathrm{RH}+2$ days shelf life. Results revealed that foliar application of $2.5 \mathrm{gl}^{-1}\left(\mathrm{CaNO}_{3}\right)_{2}$ with $0.25 \mathrm{gl}^{-1}$ or $0.5 \mathrm{gl}^{-1} \mathrm{SA}$ improved the vegetative growth characteristics (plant height, number of branches, leaves total chlorophyll contents and dry matter). Plants treated with $5 \mathrm{gl}^{-1}$ $\left(\mathrm{CaNO}_{3}\right)_{2}$ with $0.25 \mathrm{gl}^{-1} \mathrm{SA}$ gave the highest significant total yield 17.09 and 16.86 ton.fed $^{-1}$ in 2016 and 2017, respectively. Moreover, all $\left(\mathrm{CaNO}_{3}\right)_{2}$ and $\mathrm{SA}$ treatments markedly increased fruit quality at harvest and maintained their postharvest quality by decreasing fruit weight loss, shriveling and chilling injury as compared to the control treatment, in both seasons.
\end{abstract}

Keywords: $\left(\mathrm{CaNO}_{3}\right)_{2}$, Capsicum annum, Postharvest, Antioxidant, Flavonoids, Capsaicinoids

\section{INTRODUCTION}

Pepper (Capsicum annum L.) is one of the valuable Solanaceous fruity vegetables that included potato, tomato and eggplant crops. Pepper is grown as an annual crop due to its sensitivity to frost climates and is actually herbaceous perennial when grown under favorable (semi-tropical or tropical) conditions (Kelley and Boyhan, 2009, Abu-Zahra, 2012, Nkansah et al., 2017).

Peppers contain phenolics and flavonoids, carotenoids, vitamin $\mathrm{C}$, vitamin $\mathrm{E}$ and alkaloids, which play important roles in human health. In other studies, antioxidant activities in peppers were measured by radical-scavenging activity, inhibition of lipid peroxidation (Menichini et al., 2009) and metalchelating activity. Capsaicinoids and carotenoids exhibit anticancer and antioxidant activities. Flavonoids have been shown to act as antioxidants, and they possess antiinflammatory, antiallergic, and antibacterial activities. (Hong et al., 2006, Seelinger et al., 2008, AlvarezParrilla et al., 2011, Ashour et al., 2021 and Hassan et al., 2021).

Capsaicinoids are the compounds responsible for the pungency of pepper fruits and their products. Peppers are the fruits of plants from the genus Capsicum and belong to the family Solanaceae. There are several domesticated species of chili peppers, among them Capsicum annuum, C. frutescens and C. chinense, which include many common varieties. These various peppers are widely used in many parts of the world for their valued and characteristic sensory properties: color, pungency and aroma. Pungency, a commercially important attribute of peppers, is due to the presence of chemicals from the characteristic capsaicinoids group (Perucka and Materska, 2001). The two most abundant capsaicinoids in peppers are capsaicin (8-methyl- $N$ vanillyl-trans-6-nonenamide) and dihydrocapsaicin, which are constituting about $90 \%$, with capsaicin accounting for $\sim 71 \%$ of the total capsaicinoids in most of the pungent varieties. Capsaicin content of peppers is one of the major parameters that determine its commercial quality (Kawabata et al., 2006). Capsaicin and other members of the capsaicinoids group produce a large number of physiological and pharmacological effects on the gastrointestinal tract, the cardiovascular and respiratory system as well as the sensory and thermoregulation systems (Szolcsanyi, 2004).

Calcium is an important nutrient that seems to have a positive effect on fruit quality such as firmness, calcium content, organic acids, $\mathrm{pH}$, soluble solid compounds and sugars (Cummings and Reeves, 1971). Calcium has become more popular as its additional function of a secondary information transmitter was discovered. Calcium ion uptake by plants is a large extent genetically conditioned. The process of $\mathrm{Ca}$ absorption, transport, and distribution in a plant is influenced by soil, biological, and climatic factors

DOI: 10.21608/asejaiqjsae.2021.210502

${ }^{1}$ Department of Vegetable, Faculty of Agriculture,

Alexandria University, 21545- El Shatby, Alexandria, Egypt.

${ }^{2}$ Medicinal and Aromatic Plants Res. Department,

Alexandria, ARC, Egypt.

${ }^{3}$ Department of Pomology, Faculty of Agriculture,

Alexandria University, 21545- El Shatby, Alexandria, Egypt.

"Corresponding author: shaymaa.hassan@alexu.edu.eg

Received November 15, 2021, Accepted, December 20, 2021. 
(Shakoor and Bhat, 2014). Low Ca concentration in plant tissues is the main cause of various physiological disorders. One of the most frequently appearing disorders in pepper feeding in covered cultivation as well as in open fields, which happens in the period of most intense fruit growth, is blossom-end rot (BER), which destroys the usefulness of pepper, tomato, and eggplant fruits.

It needs to be mentioned that an increased quantity of $\mathrm{Ca}$ in the root environment can lead to an increased content of nutrients (lycopene, $\beta$-carotene) and to antioxidant activities in pepper (Flores et al., 2004). The application of calcium is vital and it is supported by good agricultural practices. Use of calcium improves soil physical and chemical properties, which reduced salt concentration in the soil that may enhance soil permeability (Muya and Macharia, 2003). Calcium stimulates early root formation and growth, hastens crop maturity, stimulates flowering and seed production, gives winter hardiness to fall plantings and seeding, and promotes vigorous start (cell division) to plants (Sandhya, 2014).

Salicylic acid (SA) is an endogenous growth regulator of phenolic nature, which participates in the regulation of physiological processes in plants. For example, SA is postulated to play a role as a natural inductor of thermogenesis, to induce flowering in a range of plants, to control ion uptake by roots and stomatal conductivity (Raskin, 1992). Exogenous application of SA may influence a range of diverse processes in plants, including stomatal closure, ion uptake and transport (Gunes et al., 2005), membrane permeability (Barkosky and Einhellig, 1993), as well as photosynthetic and growth rates (Khan et al., 2003). In addition to facilitating plant growth, SA plays a role in mitigating the deleterious effects of several environmental stresses on plants including low temperature and chilling (Korkmaz et al., 2007, Horvath et al., 2007), high temperature and drought (Senaratna et al., 2000), and salinity (Yildirim et al., 2008).

The present study was carried out to investigate the effect of foliar application of calcium nitrate and salicylic acid on the vegetative growth, nutritional and fruit quality characters at harvest and postharvest storability of hot pepper grown in clay loam soil under surface irrigation in open field, during 2016 and 2017.

\section{MATERIAL AND METHODS}

The experiments were carried out at the Experimental Station Farm of the Faculty of Agriculture, Alexandria University, at Abeis, Alex, Egypt, during the two summer seasons of 2016 and
2017. A split-plot system in a randomized complete blocks design (RCPD) with three replications, was adopted to study the influence of foliar application of calcium nitrate $\left(\mathrm{CaNO}_{3}\right)_{2}$ at $0,2.5$ and $5 \mathrm{~g} \mathrm{l}^{-1}$ and salicylic acid (SA) at $0,0.25$ and $0.5 \mathrm{gl}^{-1}$ as well as their interactions on the vegetative growth, yield and quality of hot pepper plants (cultivar: Omega F1). The foliar applications of calcium nitrate and salicylic acid were applied four times at 20, 40, 60 and 80 days after transplanting. Each replicate was included 9 treatments, which were the combinations of three calcium nitrate and three salicylic acid rates. The calcium nitrate were randomly arranged in the main plots, salicylic acid rates were, randomly, distributed in the sub-plots. Each subplot consisted of 3 lines, the experimental area was 7.2 $\mathrm{m}^{2}$, each replicate conducted in 27 lines $(0.6 \mathrm{~m}$ width $\times$ $4 \mathrm{~m}$ long). $194.4 \mathrm{~m}^{2}$.

Table 1. Soil physical and chemical properties of the experimental sites in the two growing seasons of 2016 and 2017

\begin{tabular}{|c|c|c|}
\hline $\begin{array}{ll} & \text { Seasons } \\
\text { Properties } & \end{array}$ & 2016 & 2017 \\
\hline $\mathrm{pH}$ & 7.71 & 8.02 \\
\hline E.C. $\left(\mathrm{dS} \cdot \mathrm{m}^{-1}\right)$ & 3.02 & 3.01 \\
\hline Sand $\%$ & 31.35 & 32.80 \\
\hline Silt \% & 25.60 & 24.60 \\
\hline Clay $\%$ & 43.05 & 42.60 \\
\hline Soil texture & Clay loam & Clay loam \\
\hline \multicolumn{3}{|l|}{$\begin{array}{l}\text { Soluble cations } \\
\left(\mathrm{meql}^{-1}\right)\end{array}$} \\
\hline $\mathrm{Ca}^{++}$ & 10.70 & 11.32 \\
\hline $\mathrm{Mg}^{++}$ & 11.37 & 11.50 \\
\hline $\mathrm{Na}^{+}$ & 3.31 & 3.14 \\
\hline $\mathrm{K}^{+}$ & 4.82 & 4.15 \\
\hline \multicolumn{3}{|l|}{$\begin{array}{l}\text { Soluble anions } \\
\left(\mathrm{meql}^{-1}\right)\end{array}$} \\
\hline $\mathrm{CO}_{3^{--}}$ & 3.25 & 3.77 \\
\hline $\mathrm{HCO}_{3}^{-}$ & 3.35 & 3.56 \\
\hline $\mathrm{Cl}^{-}$ & 5.88 & 4.80 \\
\hline $\mathrm{SO}_{4}^{--}$ & 17.72 & 17.96 \\
\hline Available P (ppm) & 0.268 & 0.431 \\
\hline
\end{tabular}

Preceding the initiation of each experiment, in both seasons, soil samples were collected, from field before planting, at $15-30 \mathrm{~cm}$ depth, and analyzed at Agricultural University analysis, for some soil's physical and chemical properties according to the published procedures (A.O.A.C, 1995, A.O.A.C International Arlington, 2019), are presented in Table 1.

Fertilization with NPK was carried out according to the recommendations for commercial production of hot pepper plant. The NPK treatment consisted of 
ammonium nitrate $\mathrm{NH}_{4} \mathrm{NO}_{3}(33 \% \mathrm{~N})$ at the level of 90 $\mathrm{kg} \mathrm{fed}{ }^{-1}$, calcium superphosphate $\left(\mathrm{Ca}\left(\mathrm{H}_{2} \mathrm{PO}_{4}\right)_{2} \cdot \mathrm{H}_{2} \mathrm{O}\right.$ $\left.\left(15 \% \mathrm{P}_{2} \mathrm{O}_{5}\right) ; 200 \mathrm{~kg} \mathrm{fed}^{-1}\right)$; and potassium sulphate $\left(\mathrm{K}_{2} \mathrm{SO}_{4}\left(48 \% \mathrm{~K}_{2} \mathrm{O}\right) ; 100 \mathrm{~kg} \mathrm{fed}^{-1}\right)$. Nitrogen fertilizer was applied thrice at 15,45 and 75 days from transplanting. Phosphorus fertilizer was mixed during soil preparation. Potassium fertilizer was applied at 15 and 45 days after transplanting.

\section{Data Recorded}

\section{Vegetative growth characters}

Random samples from five pepper plants from each sub-plot, after three months from transplanting were used to measure plant height and branching and leaf's total chlorophyll content.

\section{Leaf's chemical constituents}

Random samples from five pepper plants from each sub-plot, after three months from transplanting of pepper plants, were randomly collected, then washed with distilled water, weighed, then oven dried at $70{ }^{\circ} \mathrm{C}$ till constant weight. The $\mathrm{N}, \mathrm{P}, \mathrm{K}$ and $\mathrm{Ca}$ contents were determined in the dried leaves. The dried leaves were ground, and then a $0.3 \mathrm{~g}$ sample was digested with $\mathrm{H}_{2} \mathrm{O}_{2}$ according to A.O.A.C. (1995). Total nitrogen and phosphorus contents were determined colorimetrically using spectrophotometer at 662 and $650 \mathrm{~nm}$, according to Evenhuis (1976), while potassium and calcium were measured using a flam photometer as explained by Cottenie et al., (1982).

\section{Fruit yield, quality and postharvest storability}

Pepper fruits were manually harvested at physiological maturity stage (maximum size and green in color). The weight of the harvested fruit per each replicate was recorded periodically through the harvesting season (twice a week) to calculate the total productivity and expressed as ton per feddan. A sample of $5 \mathrm{~kg}$ per replicate was taken (three months from transplanting) and directly transported into the postharvest laboratory at Faculty of Agriculture, Alexandria University, to evaluate the fruit quality characteristics (fruit weight, length, diameter, capsaicin, Dihydrocapsaicin, Vitamins E and C). Fruits gently sorted to get rid of all unsuitable fruits (malformed, defected, mechanically injured or diseased). Uniform selected fruits per replicate $(4 \mathrm{~kg}$ per replicate) were packed in plastic boxes $40 \times 30 \times 18 \mathrm{~cm}$, and arranged in a randomized complete block design (RCBD) with three replicates per treatment. The packed fruits of all treatments were cold stored at $6 \pm 1{ }^{\circ} \mathrm{C}$ and $90 \pm 5 \%$ relative humidity, for three weeks then held for 2 days at room temperature as a shelf life. After that final fruit quality were evaluated.
Pepper fruit weight in grams was recorded by using a calibrated sensitive digital balance (Vibra CG, Japan). While the fruit length and diameter were measured using a millimeter digital vernier caliper. As for fruit weight loss, thirty fruits per replicate were selected and initial weight was recoded and reweighed at the end of the experiment. The fruit weight loss percentage was calculated as follow: Weight loss $(\%)=\left[\left(\mathrm{W}_{0}-\mathrm{W}_{1}\right) / \mathrm{W}_{0}\right]$ $\times 100$ (where $\mathrm{W}_{0}$ is the initial weight and $\mathrm{W}_{1}$ is the weight measured at sampling date). The shriveled or chilling injured fruits were visually separated at the end of this experiment and individually weighed to calculate the percentages of these defects.

\section{Capsaicin and ascorbic acid contents}

Capsaicin content in the samples was estimated by spectrophotometric measurement of the blue coloured component formed as a result of reduction of phosphomolybdic acid to lower acids of molybdenum according to (Ademoyegun et al., 2011). Capsaicin content calculated from the standard curve was expressed as $\mathrm{mg} / 100 \mathrm{~g}$ on dry basis. Capsaicin content of the chili peppers landraces analyzed was then converted in Scoville Unit by the multiplication of the gotten quantities (weight of capsaicin per dry chili pepper weight in grams) with $1.6 \times 107$ (Todd et al., 1977, Nwokem et al., 2010). The ascorbic acid content was estimated by using 2,4 dinitrophenylhydrazine reagent in conjunction with spectrophotometer at $540 \mathrm{~nm}$, and expressed as $\mathrm{mg} / 100 \mathrm{~g}$ fresh weight (Sadasivam and Manickam, 1992, Kumar and Tata, 2009).

\section{Total phenols content and antioxidant activity}

Determination of total phenolic content were measured using Folin-Ciocalteau reagent and sodium carbonate according to Swain and Hillis (1959) and Oliveira et al. (2009). A standard calibration curve of gallic acid was obtained and used to calculate total phenolic contents and expressed as milligram of gallic acid equivalents per gram of pepper. The antioxidant activity was assessed using aspectrophotometric method with the 2,2-diphenyl-1-picrylhydrazyl (DPPH) reagent. The DPPH method is based on the percentage of decrease in absorbance caused by the extract, as determined by reading the absorbance of the samples using a spectrophotometer at $517 \mathrm{~nm}$ (Brand-Williams et al., 1995). In this reaction, the DPPH species are reduced by the antioxidant constituents present in organic compounds (Morais et al., 2009). The ability to free radical sequestration was expressed as a percentage of radical oxidation inhibition, according to the following equation. The scavenging activity percentage (AA\%) was determined according to Mensor et al. (2001). 


\section{Vitamin $E$ content}

Vitamin $\mathrm{E}$ was determined according to the method of Pyka and Sliwiok (2001), using HPLC Agilent (Series 1200) equipped with autosampler injector, solvent degasser, ultraviolet (UV) detector (set at 290 $\mathrm{nm}$ ) and quaternary HP pump (Series 1100). Gradient separation was carried out with methanol and water $(9: 1, \mathrm{v} / \mathrm{v})$ as a mobile phase at a flow rate of $1.5 \mathrm{ml} / \mathrm{min}$. The column [Agilent Hypersil ODS $5 \mu \mathrm{m} 4.0 \times 2.5 \mathrm{~mm}$ ] temperature was maintained at $35^{\circ} \mathrm{C}$. The injection volume was $20 \mathrm{ml}$ of a standard of vitamin $\mathrm{E}$ in ethanol.

\section{Determination of total flavonoid and $\beta$-carotene content}

Total flavonoid content was measured by $\mathrm{AlCl} 3$ colorimetric assay according to the method of Harborne (1998) with slight modification. A calibration curve was obtained using quercetin standard $(0.1 \mathrm{mg} / \mathrm{ml})$. Total flavonoid content was expressed on dry weight basis (DW) as mg quercetin equivalents $(\mathrm{QE})$, per gram. $\beta$ carotene was determined according to the method of Pupin et al. (1999), with HPLC Agilent (Series 1200) equipped with autosampler injector, solvent degasser, ultraviolet (UV) detector (set at $280 \mathrm{~nm}$ ) and quaternary HP pump (Series 1100). The column [Agilent Hypersil
ODS $5 \mu \mathrm{m} 4.0 \times 2.5 \mathrm{~mm}$ ] temperature was maintained at $35^{\circ} \mathrm{C}$.

\section{Statistical analysis}

All the data recorded throughout the study was exposed to the analysis of variance techniques according to the design used by the CoStat software package for Windows. Treatment means were separated and compared using the L.S.D test at 0.05 level of significance according to (Snedecor and Cochran, 1980).

\section{RESULTS AND DISCUSSION}

\section{RESULTS}

\section{Vegetative growth}

Regarding to the effect of $\left(\mathrm{CaNO}_{3}\right)_{2}$ on vegetative growth as plant height and number of branches per plant of hot pepper, the higher level of $\mathrm{Ca}\left(\mathrm{NO}_{3}\right)_{2}$, significantly, enhanced plant growth in both seasons (Table 2). However, the differences on plant height and branching between $\mathrm{Ca}\left(\mathrm{NO}_{3}\right)_{2}$ and control were not significant in 2016 and 2017.

Table 2. Influence of calcium nitrate, salicylic acid and their interactions on plant height and number of branches per plant, during the summer seasons of 2016 and 2017

\begin{tabular}{|c|c|c|c|c|c|}
\hline \multirow{2}{*}{\multicolumn{2}{|c|}{ Treatments }} & \multicolumn{2}{|c|}{ Plant height $(\mathrm{cm})$} & \multicolumn{2}{|c|}{ No. of branches plant ${ }^{-1}$} \\
\hline & & 2016 & 2017 & 2016 & 2017 \\
\hline \multicolumn{6}{|c|}{ Calcium nitrate $\left(\mathrm{CaNO}_{3}\right)_{2}$} \\
\hline $0 \mathrm{gl}^{-1}$ & & $90.33 \mathrm{~B}$ & $91.44 \mathrm{~B}$ & $4.33 \mathrm{AB}$ & $4.22 \mathrm{~B}$ \\
\hline $2.5 \mathrm{gl}^{-1}$ & & $95.89 \mathrm{~B}$ & $94.44 \mathrm{~B}$ & $4.00 \mathrm{~B}$ & $4.44 \mathrm{~B}$ \\
\hline $5 \mathrm{gl}^{-1}$ & & $107.67 \mathrm{~A}$ & $108.44 \mathrm{~A}$ & $5.11 \mathrm{~A}$ & $5.55 \mathrm{~A}$ \\
\hline \multicolumn{6}{|c|}{ Salicylic acid } \\
\hline $\mathrm{SA}_{1}$ & & $96.11 \mathrm{~A}$ & $96.00 \mathrm{~B}$ & $4.33 \mathrm{~A}$ & $4.55 \mathrm{~A}$ \\
\hline $\mathrm{SA}_{2}$ & & $98.11 \mathrm{~A}$ & $98.00 \mathrm{AB}$ & $4.44 \mathrm{~A}$ & $4.67 \mathrm{~A}$ \\
\hline $\mathrm{SA}_{3}$ & & $99.67 \mathrm{~A}$ & $100.33 \mathrm{~A}$ & $4.67 \mathrm{~A}$ & $5.00 \mathrm{~A}$ \\
\hline \multicolumn{6}{|c|}{$\left(\mathrm{CaNO}_{3}\right)_{2} \mathrm{x}(\mathrm{SA})$} \\
\hline \multirow[t]{2}{*}{$0 \mathrm{gl}^{-1}$} & $\begin{array}{l}\mathrm{SA}_{1} \\
\mathrm{SA}_{2}\end{array}$ & $\begin{array}{l}85.00 \mathrm{~d} \\
90.00 \mathrm{~cd}\end{array}$ & $\begin{array}{c}86.33 \mathrm{~d} \\
91.00 \mathrm{~cd}\end{array}$ & $\begin{array}{l}4.67 \mathrm{ab} \\
3.67 \mathrm{~b}\end{array}$ & $\begin{array}{l}4.33 \mathrm{~b} \\
4.00 \mathrm{~b}\end{array}$ \\
\hline & $\mathrm{SA}_{3}$ & $96.00 \mathrm{bc}$ & $97.00 \mathrm{~b}$ & $4.67 \mathrm{a} b$ & $4.33 \mathrm{~b}$ \\
\hline \multirow{3}{*}{$2.5 \mathrm{gl}^{-1}$} & $\mathrm{SA}_{1}$ & $95.33 \mathrm{bc}$ & $92.33 \mathrm{bc}$ & $3.67 \mathrm{~b}$ & $4.00 \mathrm{~b}$ \\
\hline & $\mathrm{SA}_{2}$ & $97.67 \mathrm{~b}$ & $96.67 \mathrm{bc}$ & $5.00 \mathrm{ab}$ & $4.00 \mathrm{~b}$ \\
\hline & $\mathrm{SA}_{3}$ & $94.67 \mathrm{bc}$ & $94.33 \mathrm{bc}$ & $3.33 \mathrm{~b}$ & $5.33 \mathrm{ab}$ \\
\hline \multirow{3}{*}{$5 \mathrm{gl}^{-1}$} & $\mathrm{SA}_{1}$ & $108.00 \mathrm{a}$ & $109.33 \mathrm{a}$ & $4.67 \mathrm{ab}$ & $5.33 \mathrm{ab}$ \\
\hline & $\mathrm{SA}_{2}$ & $106.67 \mathrm{a}$ & $106.33 \mathrm{a}$ & $4.67 \mathrm{ab}$ & $6.00 \mathrm{a}$ \\
\hline & $\mathrm{SA}_{3}$ & $108.33 \mathrm{a}$ & $109.67 \mathrm{a}$ & $6.00 \mathrm{a}$ & $5.33 \mathrm{ab}$ \\
\hline
\end{tabular}

*Values followed by the same alphabetical letter(s) in common, within a particular group of means in each character, do not significantly differ, using Revised L.S.D test at 0.05 level of probability. 
Meanwhile, slight differences were noticed among levels of SA on plant height and number of branches in both seasons, except for SA at $0.5 \mathrm{gl}^{-1}$ which recorded higher significant plant height than control in 2017.

As for interaction on plant height, a synergistic effect were noticed among $\mathrm{Ca}\left(\mathrm{NO}_{3}\right)_{2}$ and $\mathrm{SA}$, especially with higher level of $\mathrm{Ca}\left(\mathrm{NO}_{3}\right)_{2}$ in both seasons. All combinations, significantly, increased plant height than $\mathrm{Ca}\left(\mathrm{NO}_{3}\right)_{2}$ at $0 \mathrm{gl}^{-1}+\mathrm{SA}$ at $0 \mathrm{gl}^{-1}$, in both seasons. Slight differences on number of branches per plant were found among almost used combinations of $\mathrm{Ca}\left(\mathrm{NO}_{3}\right)_{2}$ and SA. The highest number of branches was occurred with $\mathrm{Ca}\left(\mathrm{NO}_{3}\right)_{2}$ at $5 \mathrm{gl}^{-1}+\mathrm{SA}$ at $0.5 \mathrm{gl}^{-1}$ in 2016 and with $\mathrm{Ca}\left(\mathrm{NO}_{3}\right)_{2}$ at $5 \mathrm{gl}^{-1}+\mathrm{SA}$ at $0.25 \mathrm{gl}^{-1}$, in 2017 .

Hot pepper plants treated with $\mathrm{Ca}\left(\mathrm{NO}_{3}\right)_{2}$ at $5 \mathrm{gl}^{-1}$ had the highest significant leaf dry matter, in both seasons (Table 3). A gradual significant increase on leaf's dry matter was noticed with the increase of SA concentration, in the two seasons. In regard to the effect of interaction on leaf's dry matter, the most effective combination treatment was $\mathrm{Ca}\left(\mathrm{NO}_{3}\right)_{2}$ at $2.5 \mathrm{gl}^{-1}+\mathrm{SA}$ at
$0.5 \mathrm{gl}^{-1}$, in both seasons, in addition to $\mathrm{Ca}\left(\mathrm{NO}_{3}\right)_{2}$ at $5 \mathrm{gl}^{-1}$ + SA at $0.5 \mathrm{gl}^{-1}$ in 2016). On the other hand, the lowest significant leaf's dry matter was found with $\mathrm{Ca}\left(\mathrm{NO}_{3}\right)_{2}$ at $2.5 \mathrm{gl}^{-1}+\mathrm{SA}$ at $0 \mathrm{gl}^{-1}$,in both seasons.

Results in (Table 3) show that, no significant differences on leaf chlorophyll content were noticed among levels of $\mathrm{Ca}\left(\mathrm{NO}_{3}\right)_{2}$ in both seasons, except with $\left(\mathrm{CaNO}_{3}\right)_{2}$ at $5 \mathrm{gl}^{-1}$ which recorded higher significant chlorophyll content than control in 2016. As for SA effect on leaf's chlorophyll content, a steady increase was found with the increase of SA concentration, in both seasons. The highest SA concentration gave significantly higher leaf's chlorophyll content as compared with SA at $0 \mathrm{gl}^{-1}$, in both seasons.

Concerning to interaction effect, the lowest significant leaf's chlorophyll content was found with $\left(\mathrm{CaNO}_{3}\right)_{2}$ at $0 \mathrm{gl}^{-1}+\mathrm{SA}$ at $0.25 \mathrm{gl}^{-1}$,in 2016 and with $\left(\mathrm{CaNO}_{3}\right)_{2}$ at $2.5 \mathrm{gl}^{-1}+\mathrm{SA}$ at $0 \mathrm{gl}^{-1}$ in 2017 . Results in 2017 revealed that use of $\left(\mathrm{CaNO}_{3}\right)_{2}$ at $2.5 \mathrm{gl}^{-1}+\mathrm{SA}$ at 0.25 or $0.5 \mathrm{gl}^{-1}$ recorded the highest leaf's chlorophyll content.

Table 3. Influence of calcium nitrate, salicylic acid and their interactions on leaf's dry matter and total leaf's chlorophyll content, during the summer seasons of 2016 and 2017

\begin{tabular}{|c|c|c|c|c|c|c|}
\hline & \multirow{2}{*}{\multicolumn{2}{|c|}{ Treatments }} & \multicolumn{2}{|c|}{$\begin{array}{c}\text { Leaf's dry matter } \\
\%\end{array}$} & \multicolumn{2}{|c|}{$\begin{array}{c}\text { Leaf's Chlorophyll } \\
(\mathrm{mg} / \mathrm{g} \mathrm{Fw})\end{array}$} \\
\hline & & & 2016 & 2017 & 2016 & 2017 \\
\hline \multicolumn{7}{|c|}{ Calcium nitrate $\left(\mathrm{CaNO}_{3}\right)_{2}$} \\
\hline $0 \mathrm{gl}^{-1}$ & & & $37.17 \mathrm{~B}$ & $37.04 \mathrm{~B}$ & $71.00 \mathrm{~B}$ & $73.22 \mathrm{~A}$ \\
\hline $2.5 \mathrm{gl}^{-1}$ & & & $37.96 \mathrm{~B}$ & $37.55 \mathrm{~B}$ & $73.78 \mathrm{AB}$ & $77.00 \mathrm{~A}$ \\
\hline $5 \mathrm{gl}^{-1}$ & & & $39.59 \mathrm{~A}$ & $39.44 \mathrm{~A}$ & $76.55 \mathrm{~A}$ & $76.67 \mathrm{~A}$ \\
\hline \multicolumn{7}{|c|}{ Salicylic acid (SA) } \\
\hline $\mathrm{SA}_{1}$ & $0 \mathrm{gl}^{-1}$ & & $35.97 \mathrm{C}$ & $35.44 \mathrm{C}$ & $72.00 \mathrm{~B}$ & $72.67 \mathrm{~B}$ \\
\hline $\mathrm{SA}_{2}$ & $0.25 \mathrm{gl}^{-1}$ & & $37.49 \mathrm{~B}$ & $37.24 \mathrm{~B}$ & $73.00 \mathrm{AB}$ & $75.22 \mathrm{AB}$ \\
\hline $\mathrm{SA}_{3}$ & $0.5 \mathrm{gl}^{-1}$ & & $41.26 \mathrm{~A}$ & $41.34 \mathrm{~A}$ & $76.33 \mathrm{~A}$ & $79.00 \mathrm{~A}$ \\
\hline \multicolumn{7}{|c|}{$\left(\mathrm{CaNO}_{3}\right)_{2} \times(\mathrm{SA})$} \\
\hline \multirow{3}{*}{$0 \mathrm{gl}^{-1}$} & & $\mathrm{SA}_{1}$ & $38.46 \mathrm{~b}$ & $38.00 \mathrm{c}$ & $61.33 \mathrm{~d}$ & $75.00 \mathrm{~b}$ \\
\hline & & $\mathrm{SA}_{2}$ & $37.28 \mathrm{c}$ & $37.49 \mathrm{~cd}$ & $74.33 \mathrm{abc}$ & $66.67 \mathrm{c}$ \\
\hline & & $\mathrm{SA}_{3}$ & $35.77 \mathrm{~d}$ & $35.64 \mathrm{e}$ & $77.33 \mathrm{ab}$ & $78.00 \mathrm{ab}$ \\
\hline \multirow{3}{*}{$2.5 \mathrm{gl}^{-1}$} & & $\mathrm{SA}_{1}$ & $31.99 \mathrm{e}$ & $31.00 \mathrm{f}$ & $79.67 \mathrm{a}$ & $66.33 c$ \\
\hline & & $\mathrm{SA}_{2}$ & $37.45 \mathrm{c}$ & $36.86 \mathrm{~d}$ & $69.00 \mathrm{c}$ & $82.67 \mathrm{a}$ \\
\hline & & $\mathrm{SA}_{3}$ & $44.44 \mathrm{a}$ & $44.78 \mathrm{a}$ & $72.67 \mathrm{bc}$ & $82.00 \mathrm{a}$ \\
\hline \multirow{3}{*}{$5 \mathrm{gl}^{-1}$} & & $\mathrm{SA}_{1}$ & $37.47 . \mathrm{bc}$ & $37.33 \mathrm{~cd}$ & $75.00 \mathrm{abc}$ & $76.67 \mathrm{ab}$ \\
\hline & & $\mathrm{SA}_{2}$ & $37.74 \mathrm{bc}$ & $37.38 \mathrm{~cd}$ & $75.67 \mathrm{abc}$ & $76.33 \mathrm{ab}$ \\
\hline & & $\mathrm{SA}_{3}$ & $43.58 \mathrm{a}$ & $43.61 \mathrm{~b}$ & $79.00 \mathrm{ab}$ & $77.00 \mathrm{ab}$ \\
\hline
\end{tabular}

*Values followed by the same alphabetical letter(s) in common, within a particular group of means in each character, do not significantly differ, using Revised L.S.D test at 0.05 level of probability. 


\section{Leaf's mineral content}

Mineral content $\mathrm{N}, \mathrm{P}, \mathrm{K}$ and $\mathrm{Ca}$ of pepper leaves treated with different $\left(\mathrm{CaNO}_{3}\right)_{2}$ and $\mathrm{SA}$ factors in comparison to control treatment are presented in Table (4). Applications of $\left(\mathrm{CaNO}_{3}\right)_{2}$ at $2.5 \mathrm{gl}^{-1}$ treatment had the highest leaf's nitrogen content in 2016. On the other hand, there were no significant, in the second season. However, $\left(\mathrm{CaNO}_{3}\right)_{2}$ at $2.5 \mathrm{gl}^{-1}$ treatment had the highest leaf's phosphorus content in 2016 and 2017 (0.794\% and $0.808 \%$, respectively). Application of $\mathrm{SA}_{1}$ recorded the highest leaf's nitrogen, in two seasons and $\mathrm{SA}_{2}$ recorded the highest leaf's phosphorus content, in 2016 and $2017(0.813 \%$ and $0.812 \%$, respectively). Statistically, the differences among the mean value of the interactions were not significant regarding leaf's phosphorus content, in both seasons. Applications of $\left(\mathrm{CaNO}_{3}\right)_{2}$ at $5 \mathrm{gl}^{-1}$ treatment had the highest leaf's potassium content in 2017. On the other hand, there were no significant, in the first season. Application of $\mathrm{SA}_{1}$ recorded the leaf's potassium content was no significant, in the both seasons. The highest mean value of the leaf's calcium was recorded by $\left(\mathrm{CaNO}_{3}\right)_{2} 5 \mathrm{gl}^{-1}$, in both seasons. Results in 2017 revealed that use of $\left(\mathrm{CaNO}_{3}\right)_{2}$ at $5 \mathrm{gl}^{-1}+\mathrm{SA}_{3}$ recorded the highest leaf's calcium.

\section{Fruit yield and quality}

The pre-harvest foliar application of $\left(\mathrm{CaNO}_{3}\right)_{2}$ significantly, increased productivity of hot pepper (Table 5). The lowest fruit yield was found with control in both seasons. A steady markedly yield increase was noticed with increasing $\left(\mathrm{CaNO}_{3}\right)_{2}$ level, in both seasons. In concern to SA effect, a gradual significant increase of fruit yield with the increase of SA level, in 2016 and 2017.

As for interaction effect, all combinations of $\left(\mathrm{CaNO}_{3}\right)_{2}$ and $\mathrm{SA}$, significantly, increased fruit yield than control $\left(\mathrm{CaNO}_{3}\right)_{2}$ at $0 \mathrm{gl}^{-1}+\mathrm{SA}$ at $\left.0 \mathrm{gl}^{-1}\right)$ in both seasons. However, the highest significant yield was found with plant treated with $\left(\mathrm{CaNO}_{3}\right)_{2}$ at $5 \mathrm{gl}^{-1}+\mathrm{SA}$ at $0.25 \mathrm{gl}^{-1}$, followed by $\left(\mathrm{CaNO}_{3}\right)_{2}$ at $5 \mathrm{gl}^{-1}+\mathrm{SA}$ at 0.5 ,in 2016 and $\left(\mathrm{CaNO}_{3}\right)_{2}$ at $2.5 \mathrm{gl}^{-1}+\mathrm{SA}$ at 0.25 ,in 2017.

Fruit weight, slightly, increased with $\left(\mathrm{CaNO}_{3}\right)_{2}$ foliar application, but differences were not significant, in both seasons. However, a gradual significant increase in fruit weight was noticed with the increase of SA concentration in 2016 and 2017. The results clarified the effectiveness of SA on improving fruit weight, whereas all treatments of SA at 0.25 or $0.5 \mathrm{gl}^{-1}$ in combination with all $\left(\mathrm{CaNO}_{3}\right)_{2}$ levels, markedly, increased fruit weight, in both seasons. However, the lowest fruit weight was found with treatment of $\left(\mathrm{CaNO}_{3}\right)_{2}$ at $0 \mathrm{gl}^{-1}+$ SA at $0 \mathrm{gl}^{-1}$, in both seasons.
Hot pepper plants treated with $\left(\mathrm{CaNO}_{3}\right)_{2}$ slightly, increased fruit diameter, without significant differences, in both seasons (Table 5). Moreover, fruit diameter increased with the increase of SA concentration, without significant differences among all treatments except between $\left(\mathrm{CaNO}_{3}\right)_{2}$ at 0.25 or $0.5 \mathrm{gl}^{-1}$ and control, in 2017. Generally, no significant differences on fruit diameter among all combinations, in both seasons, except with $\left(\mathrm{CaNO}_{3}\right)_{2}$ at $5 \mathrm{gl}^{-1}+\mathrm{SA}$ at $0.5 \mathrm{gl}^{-1}$ which is significantly higher than $\left(\mathrm{CaNO}_{3}\right)_{2}$ at $0 \mathrm{gl}^{-1}+\mathrm{SA}$ at $0 \mathrm{gl}^{-}$ ${ }^{1}$ in 2016.

A steady gradual significant increase on fruit length was found with the increase of $\left(\mathrm{CaNO}_{3}\right)_{2}$ concentration, in both seasons. The differences between $\left(\mathrm{CaNO}_{3}\right)_{2}$ at 2.5 and $5 \mathrm{gl}^{-1}$ wasn't significant, in 2016 (Table 5). Furthermore, the same trend was noticed with SA, fruit length, significantly, increased with increasing SA level, in both seasons. A synergistic effect was noticed with combination of $\left(\mathrm{CaNO}_{3}\right)_{2}$ and $\mathrm{SA}$ on fruit length. The highest significant fruit length was occur with $\left(\mathrm{CaNO}_{3}\right)_{2}$ at 2.5 or $5 \mathrm{gl}^{-1}+\mathrm{SA}$ at $0.5 \mathrm{gl}^{-1}$, in both seasons, in addition to $\left(\mathrm{CaNO}_{3}\right)_{2}$ at $5 \mathrm{gl}^{-1}+\mathrm{SA}$ at $0.25 \mathrm{gl}^{-1}$, in 2016 .

\section{Nutrient content}

Application of $\left(\mathrm{CaNO}_{3}\right)_{2}$ at 2.5 and $5 \mathrm{gl}^{-1}$ achieved the mean highest values of fruit's capsaicin and dihydrocapsaicin contents (Table 6), in both seasons. The same trend was noticed fruit's capsaicin and dihydrocapsaicin contents were significantly increased with SA at $0.25 \mathrm{gl}^{-1}$ level, in both seasons. As for the interaction effect, the highest significant fruit's capsaicin contents was found with plant treated with $\left(\mathrm{CaNO}_{3}\right)_{2}$ at $5 \mathrm{gl}^{-1}+\mathrm{SA}$ at $0.25 \mathrm{gl}^{-1}$, in the first season, while, the highest means of the interaction was recorded by $\left(\mathrm{CaNO}_{3}\right)_{2} 2.5 \mathrm{gl}^{-1}$ with $0.25 \mathrm{gl}^{-1} \mathrm{SA}$, in the second season followed by $\left(\mathrm{CaNO}_{3}\right)_{2}$ at $5 \mathrm{gl}^{-1}+\mathrm{SA}$ at 0.25 . On the other hand, the highest mean values of fruit's dihydrocapsaicin contents were recorded by $\left(\mathrm{CaNO}_{3}\right)_{2} 5$ $\mathrm{gl}^{-1}$ with $0.25 \mathrm{gl}^{-1} \mathrm{SA}$, followed by $\left(\mathrm{CaNO}_{3}\right)_{2}$ at $2.5 \mathrm{gl}^{-1}+$ $\mathrm{SA}$ at 0.25 of, in both seasons.

Hot pepper plants treated with $\left(\mathrm{CaNO}_{3}\right)_{2}$ at 2.5 or 5 $\mathrm{gl}^{-1}$, slightly, increased fruit's vitamin E, ascorbic acid contents and antioxidant activity DPPH (\%), in both seasons (Table 7). Moreover, the same trend was noticed with SA, significantly increased with SA at 0.25 $\mathrm{gl}^{-1}$ or $0.5 \mathrm{gl}^{-1}$ level, in both seasons. Moreover, the highest mean values of the interaction were recorded by $\left(\mathrm{CaNO}_{3}\right)_{2}$ at $2.5 \mathrm{gl}^{-1}$ with $0.5 \mathrm{gl}^{-1} \mathrm{SA}$ in fruit's vitamin E and fruit's ascorbic acid, in both seasons. Application of $\left(\mathrm{CaNO}_{3}\right)_{2}$ at $5 \mathrm{gl}^{-1}$ with $0.5 \mathrm{gl}^{-1} \mathrm{SA}$ gave the highest mean value of antioxidant activity (DPPH), in both seasons. 
Regarding to the effect of $\left(\mathrm{CaNO}_{3}\right)_{2}$ on total phenol, $B$ carotene and flavonoids contents of hot pepper, the higher level of $\mathrm{CaNO}_{2}$ at $5 \mathrm{gl}^{-1}$, significantly, enhanced in both seasons (Table 8). However, no significant differences on total phenol among $\left(\mathrm{CaNO}_{3}\right)_{2}$ and control were detected, in 2017. Meanwhile, SA at 0.5 exhibited higher significant total phenol and $B$ carotene values, in both seasons. In the same time, slight differences were noticed among levels of SA at $0.25 \mathrm{gl}^{-1}$ or $0.5 \mathrm{gl}^{-1}$ on total flavonoids contents, in both seasons.

As for interaction on total phenol, $\beta$ carotene and flavonoids contents of hot pepper, a synergistic effect was noticed among $\left(\mathrm{CaNO}_{3}\right)_{2}$ and $\mathrm{SA}$, especially with the higher level of $\left(\mathrm{CaNO}_{3}\right)_{2}$ and SA $\left(5 \mathrm{gl}^{-1}\right.$ with $0.5 \mathrm{gl}$ ${ }^{1}$ ), in both seasons. The exception was in second season, slight differences on total phenol were found among most used combinations of $\left(\mathrm{CaNO}_{3}\right)_{2}$ and SA. The highest mean value of total phenol was occurred with $\left(\mathrm{CaNO}_{3}\right)_{2}$ at $2.5 \mathrm{gl}^{-1}+\mathrm{SA}$ at $0.25 \mathrm{gl}^{-1}$ or $0.5 \mathrm{gl}^{-1}$, followed by $\left(\mathrm{CaNO}_{3}\right)_{2}$ at $5 \mathrm{gl}^{-1}+\mathrm{SA}$ at $0.25 \mathrm{gl}^{-1}$ or 0.5 $\mathrm{gl}^{-1}$ (Table 8).

Postharvest storability
Pre-harvest treatment with $\left(\mathrm{CaNO}_{3}\right)_{2}$ at 2.5 or $5 \mathrm{gl}^{-}$ ${ }^{1}$,significantly, reduced postharvest fruit weight loss percent during cold storage for 3 weeks +2 days as a shelf life than control in both seasons (Table 9). No significant differences were noticed on weight loss among $\left(\mathrm{CaNO}_{3}\right)_{2}$ at 2.5 and $5 \mathrm{gl}^{-1}$. The same trend was found with SA treatments, both levels of 0.25 and $0.5 \mathrm{gl}^{-}$ 1 , significantly, reduced fruit weight loss percent than control, without significant differences among each other. Furthermore, the highest significant fruit weight loss was found with $\left(\mathrm{CaNO}_{3}\right)_{2}$ at $0 \mathrm{gl}^{-1}+\mathrm{SA}$ at $0 \mathrm{gl}^{-1}$, followed by $\left(\mathrm{CaNO}_{3}\right)_{2}$ at $0 \mathrm{gl}^{-1}+\mathrm{SA}$ at 0.25 or $0.5 \mathrm{gl}^{-1}$, in both seasons. All combinations, markedly, reduced weight loss percent than control, while the most effective combination treatments on reduction of weight loss were found with $\left(\mathrm{CaNO}_{3}\right)_{2}$ at 2.5 or $5 \mathrm{gl}^{-1}+\mathrm{SA}$ at 0.25 or 0.5 $\mathrm{gl}^{-1}$, in the two experimental seasons.

In regard to the effect of $\left(\mathrm{CaNO}_{3}\right)_{2}$ treatments on shriveling percent of hot pepper fruits, $\left(\mathrm{CaNO}_{3}\right)_{2}$ at 2.5 and $5 \mathrm{gl}^{-1}$, significantly, reduced shriveling percent, while $\left(\mathrm{CaNO}_{3}\right)_{2}$ at $2.5 \mathrm{gl}^{-1}$ was significantly lower than at $5 \mathrm{gl}^{-1}$ in both seasons (Table 9).

Table 4. Influence of calcium nitrate, salicylic acid and their interactions on leaf's nitrogen and phosphorus, potassium and calcium contents during the summer seasons of 2016 and 2017

\begin{tabular}{|c|c|c|c|c|c|c|c|c|c|}
\hline \multirow{2}{*}{$\begin{array}{c}\text { Treatments } \\
\text { Calcium nitrate } \\
\left(\mathrm{CaNO}_{3}\right)_{2}\end{array}$} & & \multicolumn{2}{|c|}{$\begin{array}{c}\text { Leaf's } N \text { content } \\
(\%)\end{array}$} & \multicolumn{2}{|c|}{$\begin{array}{c}\text { Leaf's P content } \\
(\%)\end{array}$} & \multicolumn{2}{|c|}{$\begin{array}{c}\text { Leaf's K content } \\
(\%)\end{array}$} & \multicolumn{2}{|c|}{$\begin{array}{c}\text { Leaf's Ca content } \\
\text { (mg/100 g DW) }\end{array}$} \\
\hline & & 2016 & 2017 & 2016 & 2017 & 2016 & 2017 & 2016 & 2017 \\
\hline $0 \mathrm{gl}^{-1}$ & & $1.98 \mathrm{AB}$ & $1.99 \mathrm{~A}$ & $0.680 \mathrm{~B}$ & $0.673 \mathrm{~B}$ & $1.59 \mathrm{~A}$ & $1.59 \mathrm{~B}$ & $4.15 \mathrm{C}$ & $4.23 \mathrm{C}$ \\
\hline $2.5 \mathrm{gl}^{-1}$ & & $2.01 \mathrm{~A}$ & $2.02 \mathrm{~A}$ & $0.794 \mathrm{~A}$ & $0.808 \mathrm{~A}$ & $1.66 \mathrm{~A}$ & $1.61 \mathrm{~B}$ & $5.28 \mathrm{~B}$ & $5.28 \mathrm{~B}$ \\
\hline $5 \mathrm{gl}^{-1}$ & & $1.95 \mathrm{~B}$ & $1.95 \mathrm{~A}$ & $0.706 \mathrm{~B}$ & $0.705 \mathrm{~B}$ & $1.67 \mathrm{~A}$ & $1.78 \mathrm{~A}$ & $6.63 \mathrm{~A}$ & $6.65 \mathrm{~A}$ \\
\hline \multicolumn{10}{|l|}{ Salicylic acid (SA) } \\
\hline $0 \mathrm{gl}^{-1}$ & & $2.13 \mathrm{~A}$ & $2.17 \mathrm{~A}$ & $0.656 \mathrm{C}$ & $0.664 \mathrm{C}$ & $1.63 \mathrm{~A}$ & $1.64 \mathrm{~A}$ & $4.80 \mathrm{~B}$ & $4.83 \mathrm{~B}$ \\
\hline $0.25 \mathrm{gl}^{-1}$ & & $1.98 \mathrm{~B}$ & $1.99 \mathrm{~B}$ & $0.813 \mathrm{~A}$ & $0.812 \mathrm{~A}$ & $1.63 \mathrm{~A}$ & $1.67 \mathrm{~A}$ & $5.56 \mathrm{~A}$ & $5.63 \mathrm{~A}$ \\
\hline $0.5 \mathrm{gl}^{-1}$ & & $1.82 \mathrm{C}$ & $1.81 \mathrm{C}$ & $0.711 \mathrm{~B}$ & $0.710 \mathrm{~B}$ & $1.67 \mathrm{~A}$ & $1.66 \mathrm{~A}$ & $5.70 \mathrm{~A}$ & $5.70 \mathrm{~A}$ \\
\hline \multicolumn{10}{|l|}{$\left(\mathrm{CaNO}_{3}\right)_{2} \mathrm{x}(\mathrm{SA})$} \\
\hline \multirow{3}{*}{$0 \mathrm{gl}^{-1}$} & $\mathrm{SA}_{1}$ & $2.07 \mathrm{~b}$ & $2.14 \mathrm{~b}$ & $0.581 \mathrm{a}$ & $0.586 \mathrm{a}$ & $1.60 \mathrm{bc}$ & $1.57 \mathrm{c}$ & $3.60 \mathrm{~d}$ & $3.66 \mathrm{f}$ \\
\hline & $\mathrm{SA}_{2}$ & $2.02 \mathrm{bc}$ & $2.02 \mathrm{c}$ & $0.662 \mathrm{a}$ & $0.637 \mathrm{a}$ & $1.58 \mathrm{~b}$ & $1.58 \mathrm{c}$ & $4.29 \mathrm{c}$ & $4.39 \mathrm{de}$ \\
\hline & $\mathrm{SA}_{3}$ & $1.84 \mathrm{e}$ & $1.82 \mathrm{e}$ & $0.797 \mathrm{a}$ & $0.796 \mathrm{a}$ & $1.61 \mathrm{bc}$ & $1.61 \mathrm{c}$ & $4.56 \mathrm{c}$ & $4.64 \mathrm{~d}$ \\
\hline \multirow{4}{*}{$2.5 \mathrm{gl}^{-1}$} & $\mathrm{SA}_{1}$ & $2.31 \mathrm{a}$ & $2.32 \mathrm{a}$ & $0.822 \mathrm{a}$ & $0.837 \mathrm{a}$ & $1.64 \mathrm{abc}$ & $1.62 \mathrm{c}$ & $4.32 \mathrm{c}$ & $4.37 \mathrm{e}$ \\
\hline & $\mathrm{SA}_{2}$ & $1.92 \mathrm{~d}$ & $1.93 \mathrm{~d}$ & $0.861 \mathrm{a}$ & $0.880 \mathrm{a}$ & $1.68 \mathrm{ab}$ & $1.61 \mathrm{c}$ & $5.79 \mathrm{~b}$ & $5.82 \mathrm{c}$ \\
\hline & $\mathrm{SA}_{3}$ & $1.79 \mathrm{e}$ & $1.82 \mathrm{e}$ & $0.699 \mathrm{a}$ & $0.707 \mathrm{a}$ & $1.66 \mathrm{abc}$ & $1.61 \mathrm{c}$ & $5.73 \mathrm{~b}$ & $5.65 \mathrm{c}$ \\
\hline & $\mathrm{SA}_{1}$ & $2.00 \mathrm{c}$ & $2.05 \mathrm{c}$ & $0.565 \mathrm{a}$ & $0.570 \mathrm{a}$ & $1.64 \mathrm{abc}$ & $1.74 \mathrm{~b}$ & $6.47 \mathrm{a}$ & $6.46 \mathrm{~b}$ \\
\hline \multirow[t]{2}{*}{$5 \mathrm{gl}^{-1}$} & $\mathrm{SA}_{2}$ & $2.02 \mathrm{bc}$ & $2.01 \mathrm{c}$ & $0.917 \mathrm{a}$ & $0.919 \mathrm{a}$ & $1.64 \mathrm{abc}$ & $1.83 \mathrm{a}$ & $6.61 \mathrm{a}$ & $6.67 \mathrm{ab}$ \\
\hline & $\mathrm{SA}_{3}$ & $1.84 \mathrm{e}$ & $1.80 \mathrm{e}$ & $0.638 \mathrm{a}$ & $0.626 \mathrm{a}$ & $1.72 \mathrm{a}$ & $1.76 \mathrm{ab}$ & $6.82 \mathrm{a}$ & $6.82 \mathrm{a}$ \\
\hline
\end{tabular}

*Values followed by the same alphabetical letter(s) in common, within a particular group of means in each character, do not significantly differ, using Revised L.S.D test at 0.05 level of probability. 
Table 5. Influence of calcium nitrate, salicylic acid and their interactions on total yield, fruit weight, diameter and length of hot pepper plants during the summer seasons of 2016 and 2017

\begin{tabular}{|c|c|c|c|c|c|c|c|c|c|}
\hline \multirow{2}{*}{$\begin{array}{c}\text { Treatments } \\
\text { Calcium } \\
\text { nitrate } \\
\left(\mathrm{CaNO}_{3}\right)_{2}\end{array}$} & & \multicolumn{2}{|c|}{$\begin{array}{l}\text { Total yield } \\
\text { ton.fed }^{-1} \text { ) }\end{array}$} & \multicolumn{2}{|c|}{$\begin{array}{l}\text { Fruit weight } \\
\text { (g) }\end{array}$} & \multicolumn{2}{|c|}{$\begin{array}{l}\text { Fruit diameter } \\
\text { (cm) }\end{array}$} & \multicolumn{2}{|c|}{$\begin{array}{l}\text { Fruit length } \\
\text { (cm) }\end{array}$} \\
\hline & & 2016 & 2017 & 2016 & 2017 & 2016 & 2017 & 2016 & 2017 \\
\hline $0 \mathrm{gl}^{-1}$ & & $9.67 \mathrm{C}$ & $9.31 \mathrm{~B}$ & $11.60 \mathrm{~A}$ & $11.10 \mathrm{~A}$ & $1.348 \mathrm{~A}$ & $1.333 \mathrm{~A}$ & $13.071 \mathrm{~B}$ & $13.180 \mathrm{C}$ \\
\hline $2.5 \mathrm{gl}^{-1}$ & & $14.76 \mathrm{~B}$ & $14.85 \mathrm{~A}$ & $11.72 \mathrm{~A}$ & $11.23 \mathrm{~A}$ & $1.359 \mathrm{~A}$ & $1.345 \mathrm{~A}$ & $13.698 \mathrm{~A}$ & $13.837 \mathrm{~B}$ \\
\hline $5 \mathrm{gl}^{-1}$ & & $15.32 \mathrm{~A}$ & $15.12 \mathrm{~A}$ & $11.79 \mathrm{~A}$ & $11.23 \mathrm{~A}$ & $1.391 \mathrm{~A}$ & $1.362 \mathrm{~A}$ & $14.084 \mathrm{~A}$ & $14.000 \mathrm{~A}$ \\
\hline \multicolumn{10}{|c|}{ Salicylic acid (SA) } \\
\hline $\mathrm{SA}_{1} \quad 0 \mathrm{gl}^{-1}$ & & $11.96 \mathrm{C}$ & $11.56 \mathrm{C}$ & $10.98 \mathrm{C}$ & $10.67 \mathrm{C}$ & $1.347 \mathrm{~A}$ & $1.313 \mathrm{~B}$ & $12.978 \mathrm{C}$ & $13.215 \mathrm{C}$ \\
\hline $\mathrm{SA}_{2} \quad 0.25 \mathrm{gl}^{-1}$ & & $13.65 \mathrm{~B}$ & $13.53 \mathrm{~B}$ & $11.79 \mathrm{~B}$ & $11.21 \mathrm{~B}$ & $1.370 \mathrm{~A}$ & $1.372 \mathrm{~A}$ & 13.743 B & $13.657 \mathrm{~B}$ \\
\hline $\mathrm{SA}_{3} \quad 0.5 \mathrm{gl}^{-1}$ & & $14.14 \mathrm{~A}$ & $14.18 \mathrm{~A}$ & $12.34 \mathrm{~A}$ & $11.67 \mathrm{~A}$ & $1.381 \mathrm{~A}$ & $1.355 \mathrm{~A}$ & $14.132 \mathrm{~A}$ & $14.145 \mathrm{~A}$ \\
\hline \multicolumn{10}{|l|}{$\left(\mathrm{CaNO}_{3}\right)_{2} \mathrm{x}(\mathrm{SA})$} \\
\hline \multirow{3}{*}{$0 \mathrm{gl}^{-1}$} & $\mathrm{SA}_{1}$ & $9.58 \mathrm{e}$ & $9.32 \mathrm{e}$ & $10.63 \mathrm{~d}$ & $10.35 \mathrm{e}$ & $1.310 \mathrm{~b}$ & $1.285 \mathrm{a}$ & $12.697 \mathrm{e}$ & $12.885 \mathrm{e}$ \\
\hline & $\mathrm{SA}_{2}$ & $8.22 \mathrm{f}$ & $7.75 \mathrm{f}$ & $11.93 \mathrm{abc}$ & $11.38 \mathrm{a}-\mathrm{d}$ & $1.360 \mathrm{ab}$ & $1.365 \mathrm{a}$ & $13.060 \mathrm{de}$ & $13.055 \mathrm{e}$ \\
\hline & $\mathrm{SA}_{3}$ & $11.20 \mathrm{~d}$ & $10.86 \mathrm{~d}$ & $12.23 \mathrm{ab}$ & $11.57 \mathrm{abc}$ & $1.373 \mathrm{ab}$ & $1.350 \mathrm{a}$ & $13.457 \mathrm{bc}$ & $13.600 \mathrm{c}$ \\
\hline \multirow{3}{*}{$2.5 \mathrm{gl}^{-1}$} & $\mathrm{SA}_{1}$ & $13.30 \mathrm{c}$ & $12.82 \mathrm{c}$ & $11.09 \mathrm{~cd}$ & $10.87 \mathrm{de}$ & $1.353 \mathrm{ab}$ & $1.310 \mathrm{a}$ & $12.853 \mathrm{e}$ & $13.285 \mathrm{~d}$ \\
\hline & $\mathrm{SA}_{2}$ & $15.62 \mathrm{~b}$ & $15.98 \mathrm{~b}$ & $\begin{array}{c}11.48 \\
\text { bcd }\end{array}$ & $11.20 \mathrm{a}-\mathrm{d}$ & $1.370 \mathrm{ab}$ & $1.400 \mathrm{a}$ & $13.850 \mathrm{~b}$ & $13.875 \mathrm{~b}$ \\
\hline & $\mathrm{SA}_{3}$ & $15.35 \mathrm{~b}$ & $15.75 \mathrm{~b}$ & $12.58 \mathrm{a}$ & $11.62 \mathrm{ab}$ & $1.353 \mathrm{ab}$ & $1.325 \mathrm{a}$ & $14.390 \mathrm{a}$ & $14.350 \mathrm{a}$ \\
\hline \multirow{3}{*}{$5 \mathrm{gl}^{-1}$} & $\mathrm{SA}_{1}$ & $13.01 \mathrm{c}$ & $12.55 \mathrm{c}$ & $11.22 \mathrm{~cd}$ & $10.80 \mathrm{c}-\mathrm{e}$ & $1.377 \mathrm{ab}$ & $1.345 \mathrm{a}$ & $13.383 \mathrm{~cd}$ & $13.475 \mathrm{~b}$ \\
\hline & $\mathrm{SA}_{2}$ & $17.09 \mathrm{a}$ & $16.86 \mathrm{a}$ & $11.96 \mathrm{abc}$ & $11.05 \mathrm{~b}-\mathrm{e}$ & $1.380 \mathrm{ab}$ & $1.350 \mathrm{a}$ & $14.320 \mathrm{a}$ & $14.040 \mathrm{~b}$ \\
\hline & $\mathrm{SA}_{3}$ & $15.85 \mathrm{~b}$ & $15.95 \mathrm{~b}$ & $12.20 \mathrm{ab}$ & $11.83 \mathrm{a}$ & $1.417 \mathrm{a}$ & $1.390 \mathrm{a}$ & $14.550 \mathrm{a}$ & $14.485 \mathrm{a}$ \\
\hline
\end{tabular}

*Values followed by the same alphabetical letter(s) in common, within a particular group of means in each character, do not significantly differ, using Revised L.S.D test at 0.05 level of probability

Table 6. Influence of calcium nitrate, salicylic acid and their interactions on fruit's capsaicin and dihydrocapsaicin contents, of hot pepper plants during the summer seasons of 2016 and 2017

Treatments

fruit's Capsaicin $(\mathrm{mg} / \mathrm{g} \mathrm{DW})$

\begin{tabular}{|c|c|c|c|c|c|}
\hline & \multirow{2}{*}{\multicolumn{2}{|c|}{$2016 \quad 2017$}} & \multirow[b]{2}{*}{2016} & \multirow{3}{*}{2017} \\
\hline & & & & & \\
\hline \multicolumn{5}{|c|}{ Calcium nitrate $\left(\mathrm{CaNO}_{3}\right)_{2}$} & \\
\hline \multicolumn{2}{|c|}{$0 \mathrm{gl}^{-1}$} & $19.11 \mathrm{~B}$ & $19.94 \mathrm{C}$ & $3.06 \mathrm{~B}$ & $2.97 \mathrm{~B}$ \\
\hline \multicolumn{2}{|l|}{$2.5 \mathrm{gl}^{-1}$} & 20.66 A & $22.88 \mathrm{~A}$ & $3.20 \mathrm{~A}$ & $3.14 \mathrm{~A}$ \\
\hline \multicolumn{2}{|l|}{$5 \mathrm{gl}^{-1}$} & $21.66 \mathrm{~A}$ & $22.66 \mathrm{~A}$ & $3.04 \mathrm{~B}$ & $3.15 \mathrm{~A}$ \\
\hline \multicolumn{6}{|c|}{ Salicylic acid (SA) } \\
\hline \multicolumn{2}{|c|}{$\mathrm{SA}_{1} \quad 0 \mathrm{gl}^{-1}$} & $19.55 \mathrm{~B}$ & $21.38 \mathrm{~B}$ & $2.91 \mathrm{C}$ & $2.92 \mathrm{~B}$ \\
\hline \multicolumn{2}{|c|}{$\mathrm{SA}_{2} \quad 0.25 \mathrm{gl}^{-1}$} & $21.88 \mathrm{~A}$ & $22.77 \mathrm{~A}$ & $3.38 \mathrm{~A}$ & $3.35 \mathrm{~A}$ \\
\hline \multicolumn{2}{|c|}{$\mathrm{SA}_{3} \quad 0.5 \mathrm{gl}^{-1}$} & $20.00 \mathrm{~B}$ & $21.33 \mathrm{~B}$ & $3.01 \mathrm{~B}$ & $3.00 \mathrm{~B}$ \\
\hline \multicolumn{6}{|c|}{$\left(\mathrm{CaNO}_{3}\right)_{2} \mathrm{x}(\mathrm{SA})$} \\
\hline \multirow{3}{*}{$0 \mathrm{gl}^{-1}$} & $\mathrm{SA}_{1}$ & $18.33 \mathrm{~d}$ & $19.50 \mathrm{~b}$ & $2.96 \mathrm{~d}$ & $2.86 \mathrm{c}$ \\
\hline & $\mathrm{SA}_{2}$ & $20.00 \mathrm{bcd}$ & $20.00 \mathrm{~b}$ & $3.23 \mathrm{~b}$ & $3.13 \mathrm{~b}$ \\
\hline & $\mathrm{SA}_{3}$ & $19.00 \mathrm{~cd}$ & $20.33 \mathrm{~b}$ & $3.00 \mathrm{~cd}$ & $2.93 \mathrm{bc}$ \\
\hline \multirow{3}{*}{$2.5 \mathrm{gl}^{-1}$} & $\mathrm{SA}_{1}$ & $19.00 \mathrm{~cd}$ & $21.00 \mathrm{~b}$ & $3.03 \mathrm{~cd}$ & $3.10 \mathrm{~b}$ \\
\hline & $\mathrm{SA}_{2}$ & $21.33 \mathrm{bc}$ & $24.33 \mathrm{a}$ & $3.46 \mathrm{a}$ & $3.36 \mathrm{a}$ \\
\hline & $\mathrm{SA}_{3}$ & $21.66 \mathrm{~b}$ & $23.33 \mathrm{a}$ & $3.10 \mathrm{c}$ & $2.96 \mathrm{bc}$ \\
\hline \multirow{3}{*}{$5 \mathrm{gl}^{-1}$} & $\mathrm{SA}_{1}$ & $21.33 \mathrm{bc}$ & $23.66 \mathrm{a}$ & $2.73 \mathrm{e}$ & $2.80 \mathrm{c}$ \\
\hline & $\mathrm{SA}_{2}$ & $24.33 \mathrm{a}$ & $24.00 \mathrm{a}$ & $3.47 \mathrm{a}$ & $3.56 \mathrm{a}$ \\
\hline & $\mathrm{SA}_{3}$ & $19.33 \mathrm{bcd}$ & $20.33 \mathrm{~b}$ & $2.93 \mathrm{~d}$ & $3.10 \mathrm{~b}$ \\
\hline
\end{tabular}

*Values followed by the same alphabetical letter(s) in common, within a particular group of means in each character, do not significantly differ, using Revised L.S.D test at 0.05 level of probability. 
Table 7. Influence of calcium nitrate, salicylic acid and their interactions on fruit's vitamins $\mathbf{E}$ and $\mathrm{C}$ contents and antioxidant activity, of hot pepper plants during the summer seasons of 2016 and 2017

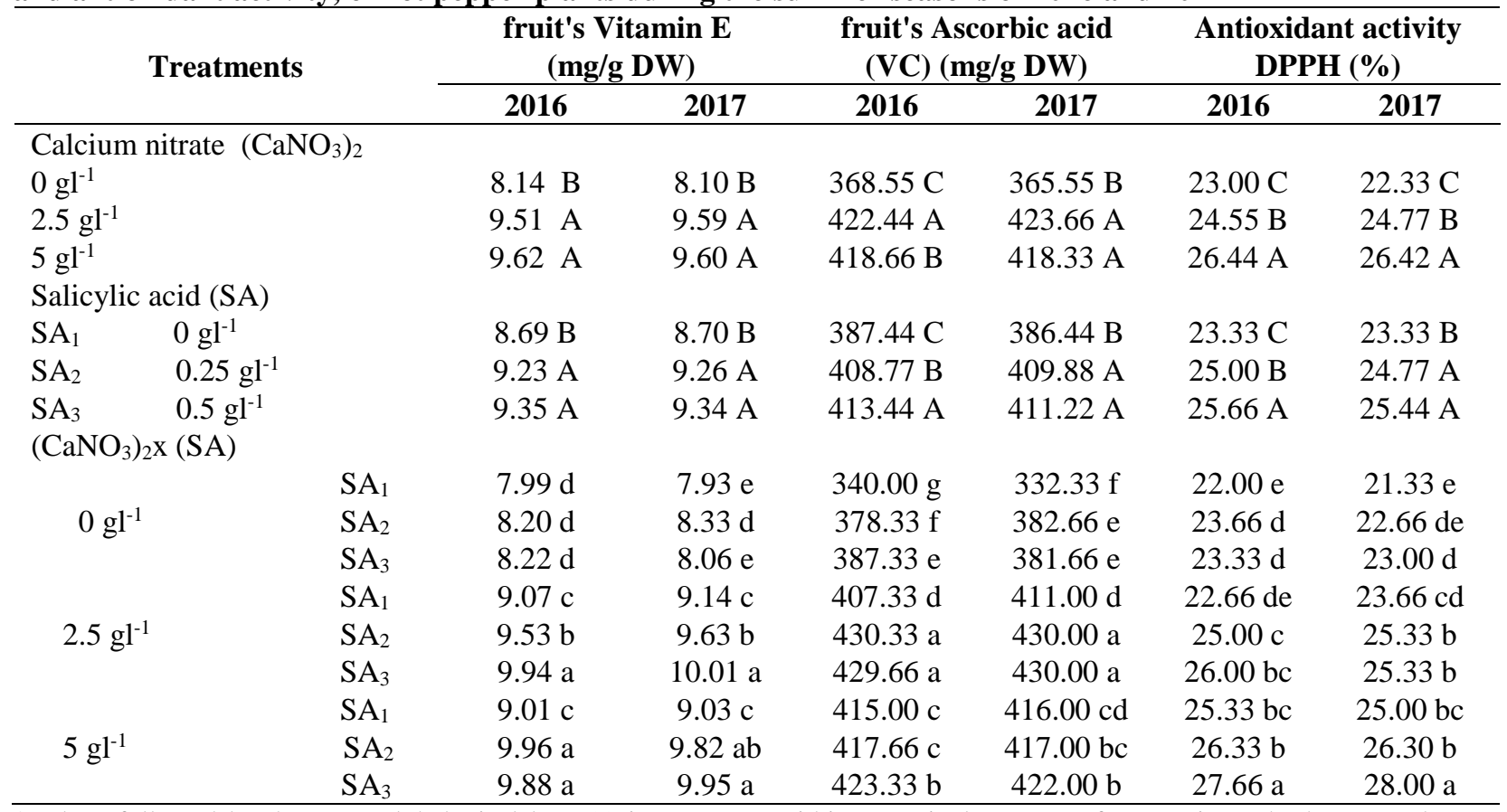

*Values followed by the same alphabetical letter(s) in common, within a particular group of means in each character, do not significantly differ, using Revised L.S.D test at 0.05 level of probability.

Table 8. Influence of calcium nitrate, salicylic acid and their interactions on fruit's total phenol, $B$ carotene and flavonoids contents of hot pepper of hot pepper plants during the summer seasons of 2016 and 2017

\begin{tabular}{|c|c|c|c|c|c|c|c|}
\hline \multirow{2}{*}{\multicolumn{2}{|c|}{ Treatments }} & \multicolumn{2}{|c|}{$\begin{array}{c}\text { Total phenol content } \\
(\mathrm{mg} / \mathrm{g} \text { DW })\end{array}$} & \multicolumn{2}{|c|}{$\begin{array}{l}\text { B carotene } \\
(\mathrm{mg} / \mathrm{g} \text { DW) }\end{array}$} & \multicolumn{2}{|c|}{$\begin{array}{c}\text { Total flavonoids conten } \\
\text { (mg/g DW) }\end{array}$} \\
\hline & & 2016 & 2017 & 2016 & 2017 & 2016 & 2017 \\
\hline \multicolumn{8}{|c|}{ Calcium nitrate $\left(\mathrm{CaNO}_{3}\right)_{2}$} \\
\hline $0 \mathrm{gl}^{-1}$ & & $19.88 \mathrm{~B}$ & $20.66 \mathrm{~A}$ & $10.79 \mathrm{C}$ & $11.02 \mathrm{C}$ & $7.82 \mathrm{C}$ & $8.92 \mathrm{~B}$ \\
\hline $2.5 \mathrm{gl}^{-1}$ & & $20.88 \mathrm{~A}$ & $22.33 \mathrm{~A}$ & $13.54 \mathrm{~B}$ & $13.83 \mathrm{~B}$ & $8.07 \mathrm{~B}$ & $8.16 \mathrm{~A}$ \\
\hline $5 \mathrm{gl}^{-1}$ & & $20.22 \mathrm{AB}$ & $20.66 \mathrm{~A}$ & $15.53 \mathrm{~A}$ & $15.44 \mathrm{~A}$ & $8.23 \mathrm{~A}$ & $8.23 \mathrm{~A}$ \\
\hline \multicolumn{8}{|c|}{ Salicylic acid (SA) } \\
\hline $\mathrm{SA}_{1}$ & $0 \mathrm{gl}^{-1}$ & $18.33 \mathrm{C}$ & $19.66 \mathrm{~B}$ & $12.48 \mathrm{C}$ & $12.67 \mathrm{C}$ & $7.92 \mathrm{~B}$ & $7.96 \mathrm{~B}$ \\
\hline $\mathrm{SA}_{2}$ & $0.25 \mathrm{gl}^{-1}$ & $20.11 \mathrm{~B}$ & $21.66 \mathrm{~A}$ & $13.41 \mathrm{~B}$ & $13.46 \mathrm{~B}$ & $8.14 \mathrm{~A}$ & $8.21 \mathrm{~A}$ \\
\hline & $0.5 \mathrm{gl}^{-1}$ & $22.55 \mathrm{~A}$ & $22.33 \mathrm{~A}$ & $13.97 \mathrm{~A}$ & $14.15 \mathrm{~A}$ & $8.07 \mathrm{~A}$ & $8.14 \mathrm{~A}$ \\
\hline \multicolumn{8}{|c|}{$\left(\mathrm{CaNO}_{3}\right)_{2} \mathrm{x}(\mathrm{SA})$} \\
\hline \multirow{3}{*}{$0 \mathrm{gl}^{-1}$} & $\mathrm{SA}_{1}$ & $18.33 \mathrm{de}$ & $18.66 \mathrm{~b}$ & $10.05 \mathrm{~h}$ & $10.41 \mathrm{~g}$ & $7.65 \mathrm{~d}$ & $7.72 \mathrm{~d}$ \\
\hline & $\mathrm{SA}_{2}$ & $19.66 \mathrm{c}$ & $21.33 \mathrm{a}$ & $10.75 \mathrm{~g}$ & $10.83 \mathrm{f}$ & $7.99 \mathrm{bc}$ & $8.15 \mathrm{ab}$ \\
\hline & $\mathrm{SA}_{3}$ & $21.66 \mathrm{~b}$ & $22.00 \mathrm{a}$ & $11.56 \mathrm{f}$ & $11.81 \mathrm{e}$ & $7.84 \mathrm{~cd}$ & $7.89 \mathrm{~cd}$ \\
\hline \multirow{3}{*}{$2.5 \mathrm{gl}^{-1}$} & $\mathrm{SA}_{1}$ & $19.33 \mathrm{~cd}$ & $21.66 \mathrm{a}$ & $12.31 \mathrm{e}$ & $12.57 \mathrm{~d}$ & $7.99 \mathrm{bc}$ & $8.05 \mathrm{bc}$ \\
\hline & $\mathrm{SA}_{2}$ & $21.33 \mathrm{~b}$ & $22.66 \mathrm{a}$ & $13.77 \mathrm{~d}$ & $14.08 \mathrm{c}$ & $8.11 \mathrm{ab}$ & $8.27 \mathrm{ab}$ \\
\hline & $\mathrm{SA}_{3}$ & $22.00 \mathrm{~b}$ & $22.66 \mathrm{a}$ & $14.54 \mathrm{c}$ & $14.85 \mathrm{~b}$ & $8.13 \mathrm{ab}$ & $8.18 \mathrm{ab}$ \\
\hline \multirow{3}{*}{$5 \mathrm{gl}^{-1}$} & $\mathrm{SA}_{1}$ & $17.33 \mathrm{e}$ & $18.66 \mathrm{~b}$ & $15.09 \mathrm{~b}$ & $15.04 \mathrm{~b}$ & $8.12 \mathrm{ab}$ & $8.11 \mathrm{bc}$ \\
\hline & $\mathrm{SA}_{2}$ & $19.33 \mathrm{~cd}$ & $21.00 \mathrm{a}$ & $15.70 \mathrm{a}$ & $15.47 \mathrm{a}$ & $8.32 \mathrm{a}$ & $8.23 \mathrm{ab}$ \\
\hline & $\mathrm{SA}_{3}$ & $24.00 \mathrm{a}$ & $22.33 \mathrm{a}$ & $15.80 \mathrm{a}$ & $15.80 \mathrm{a}$ & $8.26 \mathrm{a}$ & $8.36 \mathrm{a}$ \\
\hline
\end{tabular}

*Values followed by the same alphabetical letter(s) in common, within a particular group of means in each character, do not significantly differ, using Revised L.S.D test at 0.05 level of probability. 
Table 9. Influence of calcium nitrate, salicylic acid and their interactions on fruit weight loss, shriveling and chilling injury percentage, after 3 weeks of cold storage at $6 \pm 1{ }^{\circ} \mathrm{C}$ and $90 \pm 5 \% \mathrm{RH}+2$ days shelf life during the summer seasons of 2016 and 2017

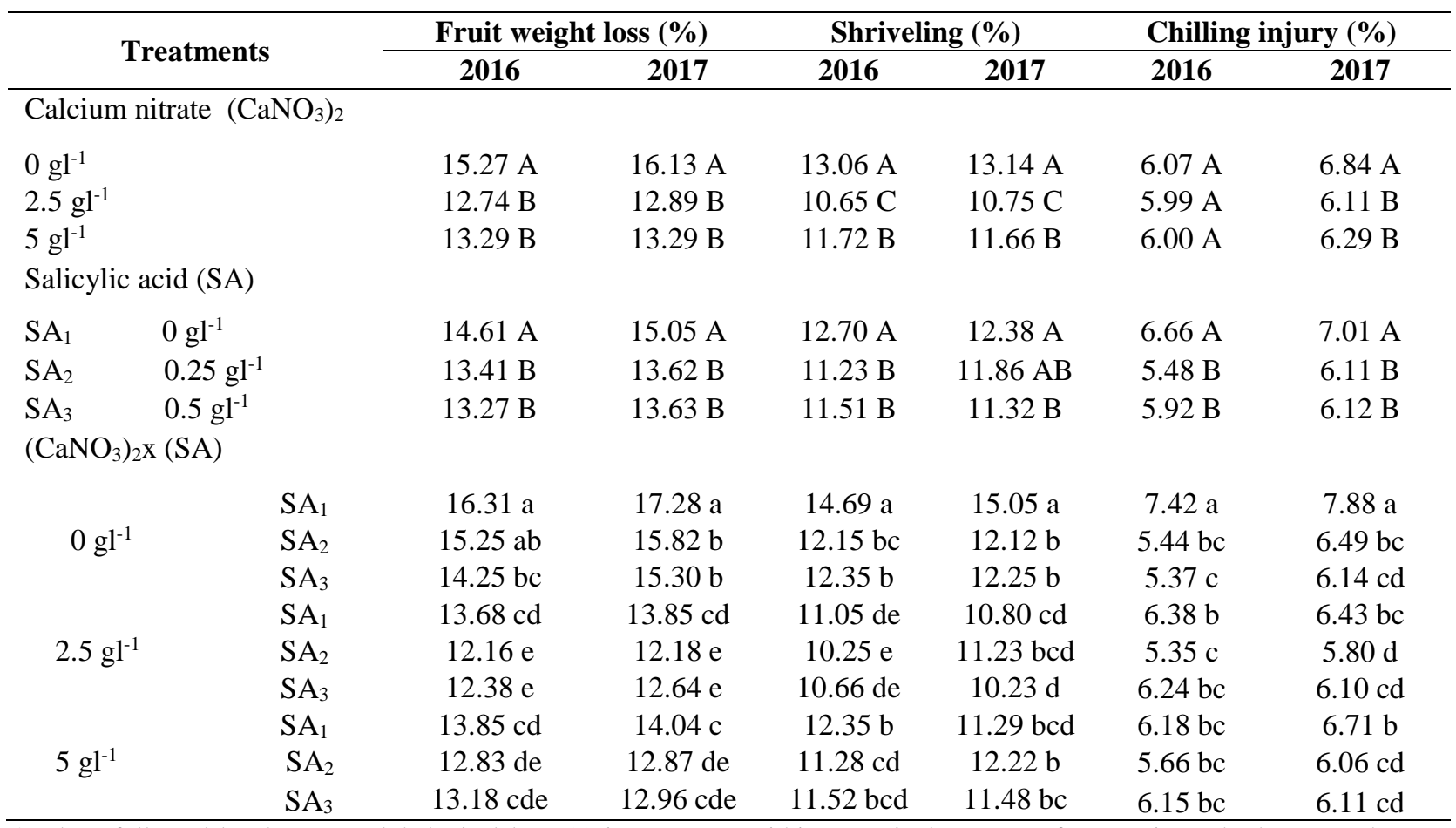

*Values followed by the same alphabetical letter(s) in common, within a particular group of means in each character, do not significantly differ, using Revised L.S.D test at 0.05 level of probability

Moreover, the use of SA at $0.5 \mathrm{~g}^{-1}$ in both seasons and $0.25 \mathrm{gl}^{-1}$ in 2016, significantly, reduced shriveling percent than control. Concerning to interaction effect, all combinations with $\left(\mathrm{CaNO}_{3}\right)_{2}$ at 2.5 or $5 \mathrm{gl}^{-1}+\mathrm{SA}$ at 0.25 or $0.5 \mathrm{gl}^{-1}$, significantly, reduced fruit shriveling than those of $\left(\mathrm{CaNO}_{3}\right)_{2}$ at $0 \mathrm{gl}^{-1}+\mathrm{SA}$ at $0 \mathrm{gl}^{-1}$, in both seasons. The most effective treatment reducing shriveling percent was found with $\left(\mathrm{CaNO}_{3}\right)_{2}$ at $2.5 \mathrm{gl}^{-1}+$ $\mathrm{SA}$ at $0.25 \mathrm{gl}^{-1}$ and $\left(\mathrm{CaNO}_{3}\right)_{2}$ at $2.5 \mathrm{gl}^{-1}+\mathrm{SA}$ at $0.5 \mathrm{gl}^{-1}$, in 2016 and 2017, respectively.

Pre-harvest treatment with $\left(\mathrm{CaNO}_{3}\right)_{2}$ and SA, significantly, alleviated postharvest chilling injury on hot pepper fruit after cold storage at $6 \pm 1{ }^{\circ} \mathrm{C}$ and $90 \pm 5 \%$ RH for 3 weeks +2 days as a shelf life (Table 9). Application of $\left(\mathrm{CaNO}_{3}\right)_{2}$ at $2.5 \mathrm{gl}^{-1}$ was the most effective treatment on reduction of $\mathrm{CI}$, in both seasons. However, both levels of SA at 0.25 and $0.5 \mathrm{gl}^{-1}$, significantly, reduced CI as compared with control, in both seasons. The interaction of $\left(\mathrm{CaNO}_{3}\right)_{2}$ and $\mathrm{SA}$ levels, in both seasons clarified that all combinations, significantly, reduced the incidence of CI on hot pepper fruits as compared with control $\left(\mathrm{CaNO}_{3}\right)_{2}$ at $0 \mathrm{gl}^{-1}+\mathrm{SA}$ at $\left.0 \mathrm{gl}^{-1}\right)$, in both seasons. The lowest percent of CI was found with $\left(\mathrm{CaNO}_{3}\right)_{2}$ at $2.5 \mathrm{gl}^{-1}+\mathrm{SA}$ at $\left.0.25 \mathrm{gl}^{-1}\right)$

\section{DISCUSSION}

\section{Vegetative growth}

Mineral nutrients are generally applied to plants to ensure adequate growth and yield. However, mineral nutrients may also exert secondary influences on the growth and yield of plants by causing changes in chemical composition, plant morphology and anatomy which may affect their resistance to pests and diseases. Calcium ion is one of the essential nutrient associate with healthy growth and development higher yield and fruit quality. Calcium mainly involved in the formation of plant cell wall, furthermore it is signaling molecule, which regulates a wide range of physiological and pathological reactions (Malinovsky et al., 2014). Also, the application of calcium sources at high rate can be used to improve soil properties and increase the available nutrients. The application of calcium sources: calcium sulphate and calcium nitrate led to enhanced yield and yield components of bulb garlic plants under saline soil conditions (Khaled et al., 2019). 
Salicylic acid is a natural phenolic acid, endogenous growth regulator, plays many regulative functions in plant metabolism (Karlidag et al., 2009).

\section{Fruit yield and quality}

A steady markedly yield increase was noticed with increasing $\left(\mathrm{CaNO}_{3}\right)_{2}$ level, in both seasons (Table 5). A positive influence of $\mathrm{Ca}$ feeding on the total and marketable yield of pepper fruit compared with the control treatment (Buczkowska et al.,2016). The additional application of calcium in the field cultivation of pepper plant had positive effects on the total yield (El-Tohamy et al., 2006). Calcium application even preharvest or postharvest significantly maintain fruit quality, delay deterioration rate and prolong storability of several crops (Basiouny and Basiouny, 2000). Occur of $\mathrm{Ca}$ at suitable level in plant tissues help to maintain quality of pepper fruits due to control of membrane permeability and slow the ripening process during storage (Poovaiah, 1986).

\section{Nutrient content}

Salicylic acid (SA) and Calcium nitrate $\left(\mathrm{CaNO}_{3}\right)_{2}$ increases capsaicin and dihydrocapsaicin contents in fruit may due to the peroxidase enzyme by catalytic activity, through the direct effect of salicylic acid and calcium nitrate on inhibiting this enzyme activity. Among the vitamins, ascorbic acid is the least stable and easily destroyed during storage process and is thus very sensitive to degradation (Spinardi, 2005). The use of $\left(\mathrm{CaNO}_{3}\right)_{2}$ had a positive effect on the accumulation of vitamin $\mathrm{C}$ and carotenoids as compared with other fertilizers (Buczkowska et al.,2016) .As an important component of the antioxidative defense mechanism in cells and tissues, vitamin $\mathrm{C}$ acts as a reducing and a chelating agent and has been shown to scavenge free radicals. Salicylic acid as an antioxidant activates ascorbate peroxidase, which, in turns, increases antioxidant ability and ascorbic acid amount in fruits. Antioxidant activity was also affected by salicylic acid, as the results showed. As can be seen in Table 6,7 and 8. The current results were in agreement with the findings reported on strawberry (Shafiee et al., 2010), pear (Cao et al., 2006) and apricot (Ardakani, et al., 2013). Salicylic acid (SA) and Calcium nitrate $\left(\mathrm{CaNO}_{3}\right)_{2}$ increases antioxidant activity through the expression of oxidase gene, removes toxic effects of free radicals and protects plant cell tensions against all kinds of stresses (Turnham, 1990, Zhang and Schmidt, 1999). Pila, et al. (2010) stated that salicylic acid increased the activity of phenylalanine ammonia-lyase enzyme, a key enzyme in the phenylpropanoids metabolism, enhanced the synthesis and accumulation of important phenolic compounds with antioxidant properties, and finally increased tissue resistance to living and non-living stressors. Data obtained on the influence of Salicylic acid (SA) and Calcium nitrate $\left(\mathrm{CaNO}_{3}\right)_{2}$ on total phenolics, B-carotene and flavonoids content showed that enhancement in duration of shelf life led to the reduction of total phenolic contents, so that the highest phenolic and flavonoids content were obtained at 5 gl-1 $\left(\mathrm{CaNO}_{3}\right)_{2}$ and $0.5 \mathrm{gl}-1 \mathrm{SA}$ (Table 8). Phenolic compounds are the main contributors to functional quality and have a leading role in counteracting reactive oxygen species, thus minimizing molecular damage. Based on Remorini, et al. (2008), decrease in fruit phenolic contents during shelf life is related to the chemical and enzymatic changes occurring during fruit development. Generally, phenolic compounds are reduced during fruit growth and development, which lead to the reduction of astringency. It is suggested that phenolic compounds are incorporated in enzymatic and non-enzymatic reactions during storage, and that may be the reason for lower contents of this chemicals (Sartip and Hajilou, 2015). Regarding the effect of salicylic acid on total phenolics contents, results showed that an increase in salicylic acid concentration brought about a significant increase in total phenolics, B-carotene and flavonoides content.

\section{Postharvest storability}

Preharvest foliar spray with $\mathrm{CaCl}_{2}$ solutions exhibited higher quality and lower softening rates than those of controls at both shelf life and cold storage at $0^{\circ} \mathrm{C}$ on kiwifruits (Gerasopoulos et al., 1996). Calcium salts may influence rotting in several different ways. Firstly, by direct effects on the growth and development of the fungus and, secondly, by increasing the resistance of the host crop to rotting. Calcium salts have also been shown to enhance the efficacy of bio-control agents.

Results of this study revealed that SA maintained pepper fruit quality and delayed fruit softening and shriveling after cold storage and shelf life. This effect may be due to reduction of ethylene production which subsequently decreased activity of cell wall degrading enzymes. Salicylic acid has a positive effect on reducing ethylene production and subsequently inhibits cell wall and membrane degrading enzymes such as polygalacturonase, lipoxygenase, cellulase and pectine methylesterase leading to decreasing the fruit softening rate (Srivastava and Dwivedi, 2000; Zhang et al., 2003). The effects of SA on maintaining pepper fruit quality were in harmony with findings on kiwifruit (Aghdam et al., 2009), bananas (Srivastava and Dwivedi, 2000), and peach (Wang et al., 2006).

Furthermore, SA was effective in reduction of water loss and alleviating incidence of chilling injury, this may be due to the antioxidant effect of SA, which plays a significant role on maintaining plasma membrane integrity which retard water loss and reduction of 
oxidative stresses leading to maintain cell compartmentalization.

Furthermore, SA treatments significantly reduced the incidence of decay during cold storage and shelf life of pepper fruits (data not shown). These results may be contributed to the antimicrobial effect of SA by inducing a defense system (Chan and Tian, 2006). (Xu and Tian, 2008) reported that SA enhancing activities of antioxidant enzymes which increased resistance against fungal attack in treated fruits. These results were in agreement with (Wang et al., 2006) on peach, (Xu and Tian 2008) on sweet cherry and (Babalar et al., 2007) on strawberry.

\section{CONCLUSION}

Calcium and salicylic acid are an important nutrient that seems to have a positive effect on vegetative growth, total yield and fruit quality. This study clarified the effect of foliar calcium nitrate and salicylic acid on the vegetative, nutritional and fruit quality characters at harvest and postharvest. Moreover, calcium nitrate $\left(\mathrm{CaNO}_{3}\right)_{2}$ and salicylic acid led to decreased fruit weight loss, shriveling and chilling injury of hot pepper plants under clay loam soil conditions.

\section{REFERENCES}

Abu-Zahra, T. R.2012.Vegetative, flowering and yield of sweet pepper as influenced by agricultural practices. Middle-East Journal of Scientific Research, 11(9):12201225 .

Ademoyegun, O.T., T.A. Fariyike and R.B. Aminu-Taiwo. 2011. Effects of poultry dropping on the biologically active compounds in capsicum annuum L (var. Nsukka yellow). Agric. Biol. J. N. Am., 2(4): 665-672.

Aghdam, M.S., Y. Mostofi, A.Motallebiazar, M.Ghasemneghad, and M.J. Fattahi.2009. Effects of MESA vapar treatment on the postharvest quality of Hayward kiwifruit. In 6 Int. Postharvest Symposium.Antalya. Turkey.

Alvarez-Parrilla, E., L.A. de la Rosa, R. Amarowicz, F. Shahidi.2011. Antioxidant activity of fresh and processed Jalapeño and Serrano peppers. J Agric Food Chem 59: 163-173.

Amruthraj,N.J., J.P.P. Raj and L.A. Lebel.2014. Effect of vegetable oil in the solubility of capsaicinoids extracted from capsicum Chinense Bhut Jolokia. Asian J. Pharm. Clin. Res., 7(1): 48-51.

A.O.A.C. 1995 . Official tentative methods of analysis. $12^{\text {th }}$ Ed. Washington, D. C., U.S.A.

A.O.A.C International Arlington.2019. Official methods of analysis, AOAC International.
Ardakani, A., G.H. Davarynejad, M. Azizi .2013. Impact of pre-harvest spry salicylic acid application on storability, postharvest quality and antioxidant activity apricot (Prunus armeniaca L). Journal of Horticulture Science 26(4):448-459.

Ashour, M., S.M. Hassan, M.E. Elshobary, G.A.G. Ammar, A. Gaber, W.F. Alsanie, A.T.Mansour and R.ElShenody.2021. Impact of commercial seaweed liquid extract $\left(\mathrm{TAM}^{\circledR}\right)$ biostimulant and Its bioactive molecules on growth and antioxidant activities of hot pepper (Capsicum annuum). 2021.Plants 10,.1045. https://doi.org/10.3390/ Actindia chinensis plants 10061045.

Babalar, M., M. Asghari, A. Talaei, and A. Khosroshahi.2007. Effect of pre- and postharvest salicylic acid treatment on ethylene production, fungal decay and overall quality of Selva strawberry fruit. Food Chem. 105: 449-453.

Barkosky, R. R., F. A. Einhellig .1993. Effects of salicylic acid on plant water relationship. J. Chem. Ecol. 19: 237247.

Basiouny, F.M., and A.Basiouny.2000. Effects of liquid calcium and controlled atmosphere on storability and quality of kiwifruit (Planch cv. Hayward). Acta Hort. 518: 213-221.

Brand-Williams, W., M. E. Cuvelier, and C.Berset.1995. Use of a free radical method to evaluate antioxidant activity. Lebensmittel Wissenscharft and Technologies, 28 (1):2530.

Buczkowska ,H., Z. Michalojc, and R.N. Wierdak.2016. Yield and fruit quality of sweet pepper depending on foliar application of calcium. Turk J Agric For40: 222-228.

Cao, J., K. Zeng, W. Jiang.2006. Enhancement of postharvest disease resistance in $\mathrm{Ya} \mathrm{Li}$ pear (Pyrus bretschneideri) fruit by salicylic acid sprays on the trees during fruit growth. European Journal of Plant Pathology 114(4):363370.

Chan, Z. L. and S.Tian .2006. Induction of $\mathrm{H}_{2} \mathrm{O}_{2}$-metabolizing enzymes and total protein synthesis by antagonistic yeast and salicylic acid in harvested sweet cherry fruit. Postharvest Biology and Technology. 39:314-320.

Cottenie, A., M. Verloo, L. Kiekers, G. Velghe and R. Camrbynek.1982. Chemical analysis of plants and soils. State Univ. Hand Book, 1-63, Ghent, Belgium.

Cummings ,G.A, and J.Reeves. 1971. Factors influencing chemical characteristics of peaches. Journal of the American Society for Horticultural Science 96, 320-322.

El-Tohamy, W.A., A.A. Ghoname, S.D. Abou-Hussein .2006. Improvement of pepper growth and productivity in sandy soil by different fertilization treatments under protected cultivation. J. Appl.Sci. Res 2: 8-12

Evenhuis, B.1976. Simplified methods for foliar analysis parts.I.VII. International Report. Royal Tropical. Institute, Amestrdam.

Flores, P., J.M. Navarro, C. Garido, J.S .Rubio, V. Martinez.2004. Influence of $\mathrm{Ca}^{+2}, \mathrm{~K}^{+}$and $\mathrm{NO}^{-3}$ fertilization on nutritional quality of pepper. J Sci Food Agric 84: 569-574. 
Gerasopoulos, D., V. Chouliaras, and S.Lionakis .1996. Effect of preharvest calcium chloride sprays on maturity and storability of Hayward kiwifruit. Postharvest Biol. Technol. 7: 65-72.

Gunes, A., A.Inal, M.Alpaslan, , N.Cicek, E. G. Bag , F.Eraslan, and T.Guzelordu. .2005. Effects of exogenously applied salicylic acid on the induction of multiple stress tolerance and mineral nutrition in maize (Zea mays L.). Arch. Agron. Soil Sci. 51: 687-695.

Hassan, S. M., A. F. E.1-Bebany, M. Z.Salem and D. A. Komeil .2021. Productivity and post-harvest fungal resistance of hot pepper as affected by potassium silicate, clove extract foliar spray and nitrogen application. Plants, 10(4) :1-18.

Harborne , A.J.1998. Phytochemical methods a guide to modern techniques of plant analysis. ${ }^{3} \mathrm{rd}$ (Ed) Phytochemical methods 317: 60-65.

Hervert-Hernández, D., S.G. Sáyago-Ayerdi and I. Gõni .2010. Bioactive compounds of four hot pepper varieties (Capsicum annuum L.), antioxidant capacity, and intestinal bioaccessibility. J Agric Food Chem 58: 33993406.

Hong ,H., M.R. Landauer, M.A. Foriska and G.D. Ledney .2006. Antibacterialactivity of the soy isoflavone genistein. J Basic Microbiol 46: 329-335.

Horvath, E., S. Szalai, T.Janda.2007. Induction of abiotic stress tolerance by salicylic acid signaling. J. Plant Growth Regul. 26: 290-300.

Khaled, A. H. S., A. E.A. Abd El-All and F. H. A. El-Agyzy. 2019. Effect of different calcium sources on some soil chemical properties and garlic (Allium sativum L.) productivity under saline soil conditions. Alexandria Science Exchange Journal.40 (4):693-704.

Khan, W., B.Prithiviraj, and D. L. Smith.2003. Photosynthetic responses of corn and soybean to foliar application of salicylates. J. Plant Physiol. 160: 485-492.

Karlidag, H., E.Yildiri and M.Turan. 2009. Salicylic acid ameliorates the adverse effect of salt stress on strawberry. Sci. Agr. 66:180-87.

Kawabata, F., N.Inoue, S.Yazawa, T.Kawada, K.Inoue and T.Fushiki.2006. Effects of CH-19 sweet,a non-pungent cultivar of red pepper, in decreasing the body weight and suppressing body fat accumulation by sympathetic nerve activation in humans. Biosci. Biotechnol. Biochem., 70: 2824-2835.

Kelley, W., G.Boyhan.2009. Commercial pepper production handbook. The university of georgia, cooperative extension.

Kumar, O.A. and S.S. Tata.2009. Ascorbic acid contents in chili peppers (Capsicum L.). Not. Sci. Biol., 1 (1): 50-52.

Malinovsky, F.G., J.U. Fangel and W.G.T. Willats.2014. The role of the cell wall in plant immunity. Frontiers in Plant Science 5: 1-12.

Menichini, F., R. Tundis, M. Bonesi, R.M. Loizzo, and F. Conforti. 2009. The influence of fruit ripening on the phytochemical content and biological activity of Capsicum chinense Jacq. cv Habanero. Food Chem 114: 553-560.
Mensor, L. L., F. S. Menezes, G. G. Leitao, A. S.Reis , T. C. Dos Santos, and C. S Coube.2001. Screening of Brazilian plant extracts for antioxidant activity by the use of DPPH free radical method.Phytotherapy Research, 15: 127-130.

Morais, S. A. L., F. J. T.Aquino, P. M.Nascimento, and E. A. Nascimento.2009. Compostos bioativos E atividade antioxidante do café conilon submetido A diferentes graus de torra. Quimica Nova.. 32(2): 327-331.

Muya, E.M. and P.N. Macharia.2003. Effects of irrigation and soil fertility management technologies on the productivity of saline-sodic soils, Kajiado District, Kenya. Proceedings of East African Soil Society Conference held in Eldoret, Kenya on ${ }^{1}$ st to ${ }^{6}$ th December.

Nkansah, G., J. Norman, A.Martey.2017. Growth, yield and consumer acceptance of sweet pepper (Capsicum annuum l.) as influenced by open field and greenhouse production systems. J Hortic. 4(4): 1-8.

Nwokem, C.O., E.B.Agbaji, J.A. Kagbu and E.J. Ekanem.2010. Determination of capsaicin content and pungency level of five different peppers grown in nigeria. New York Science Journal, 3(9): 17-21.

Oliveira, A. C., I. B Valentim, M. O.Fonseca-Goulart, C. A. Silva, E. J. H. Bechara and M. T. S.Trevisan.2009. Fontes vegetais naturais de antioxidantes. Química Nova.32:689702 .

Perucka, I., M.Materska.2001. Phenylalanine ammonia-lyase and antioxidant activities of lipophilic fraction of fresh pepper fruits Capsicum annuum L. Innovat. Food Sci. Emerg. Tech. 2: 189-192.

Pila ,N., N.B. Gol, T.R. Rao.2010. Effect of post harvest treatments on physicochemical characteristics and shelf life of tomato (Lycopersicon esculentum Mill.) fruits during storage. American-Eurasian Journal of Agricultural and Environmental. 9(5): 470-479.

Poovaiah, B.W.1986. Role of calcium in prolonging storage life of fruits and vegetables. Food Technol. 40(5): 86-89.

Pupin, M.A., J.M. Dennis and F.C.M. Toledo.1999. HPLC analysis of carotenoids in orange juice. Food Chem 64: 269-275.

Raskin, I.1992. Role of salicylic acid in plants. Annu. Rev. Plant Physiol. Plant Mol. Biol. 43: 439-463.

Remorini,D., S. Tavarini, E. Degl'Innocenti, F .Loreti, R .Massai and L. Guidi.2008. Effect of rootstocks and harvesting time on the nutritional quality of peel and flesh of peach fruits. Food Chemistry .110(2): 361- 367.

Sadasivam , S. and A. Manikkam.1992. Capsaicin. In Biochemical methods for agricultural sciences, Wiely Estern Ltd., Madras.pp. 193-194.

Sandhya, B.2014. Comparative study of rock phosphate and calcium phosphate on the growth and biochemistry of Brassica Juncea and its impact on soil heath. Journal of Environmental Science, Toxicology and Food Technology. 8 (11): 22- 39.

Sartip, G., J.Hajilou.2015. Effect of preharvest application salicylic acid on physicochemical characteristics of apricot (Prunus armeniaca l.) fruits cv. 'Shamlou' during storage. Journal of Crops Improvement .17(1): 81-91. 
Seelinger, G., I. Merfort, U. Wölfle, C.M. Schempp.2008. Anti-carcinogenic effects of the flavonoid luteolin. Molecules .13: 2628-2651.

Senaratna, T., D.Touchell, E.Bunn, and K.Dixon.2000. Acetyl salicylic acid (Aspirin) and salicylic acid induce multiple stress tolerance in bean and tomato plants. Plant Growth Regul. 30: 157-161.

Shafiee ,M., T.S. Taghavi, M. Babalar.2010. Addition of salicylic acid to nutrient solution combined with postharvest treatments (hot water, salicylic acid, and calcium dipping) improved postharvest fruit quality of strawberry. Scientia Horticulturae .124(1): 40-45.

Shakoor, S.A., M.A. Bhat.2014. Biomineralisation of silicon and calcium in plants and its control: an overview. Plant 2: 6-13.

Snedecor, G. W. and W. G. Cochron.1980. Statistical method, $7^{\text {th }}(\mathrm{Ed})$. Iowa State University Press, Ames,pp.507.

Spinardi, A.M.2005. Effect of harvest date and storage on antioxidant systems in pears. Acta Horticulturae.682:135140.

Srivastava, M. K., and U. N. Dwivedi.2000. Delayed ripening of banana fruit by salicylic acid. Plant Sci. 158: 87-96.

Swain, T.,and W. E.Hillis .1959. The phenolic constituents of Prunus domestica. The quantitative analysis of phenolic constitutents. Journal Science Food Agricuture. 10 (1): 63 68.

Szolcsanyi, J.2004. Forty years in capsaicin research for sensory pharmacology and physiology.Neuropeptides . 38: 377-384.

Thurnham, D.I. 1990. Antioxidants and prooxidants in malnourished populations. proceedings of the Nutrition Society. 49(02): 247-259.

Todd, P., M.Bensinger and T. Biftu.1977. Determination of pungency due to capsicum by gas-liquid chromatography. Journal of Food Science. 42: 660-665

Wang, L.J., S.J.Chen, W.F. Kong, S.H. Li, and D.D. Archbold.2006. Salicylic acid pretreatment alleviates chilling injury and effects the anti-oxidant system and heat shock proteins of peaches during cold storage. Postharvest Biology and Technology. 41: 244-251.

$\mathrm{Xu}, \mathrm{X}$., and S.Tian.2008. Salicylic acid alleviated pathogeninduced oxidative stress in harvested sweet cherry fruit. Postharvest Biology and Technology. 49: 379-385.

Yildirim, E., M.Turan, and I.Guvenc. 2008. Effect of foliar salicylic acid applications on growth, chlorophyll and mineral content of cucumber (Cucumis sativus L.) grown under salt stress. J. Plant Nutr. 31, 593-612.

Zhang, X., R.E. Schmidt. 1999. Biostimulating turfgrasses. Grounds Maintenance 34:14-15. 


\section{الملخص العربي}

\section{تحسين النمو والإنتاجية وجودة الثمار والقدرة التخزينية للقلفل الحار بعد الحصاد بواسطة الرش بنترات الكالسيوم وحامض الساليسيليك \\ شيماء محمد رجب على حسن ، زينب عبد الحافظ ، يحيى صلاح مصطفى}

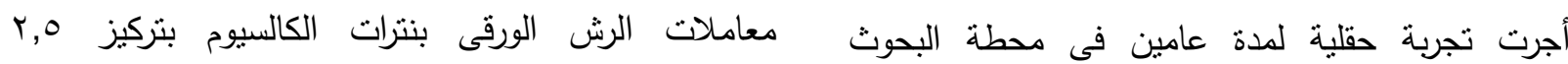

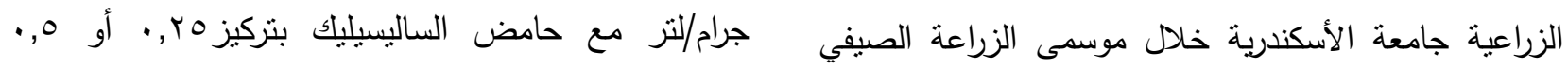

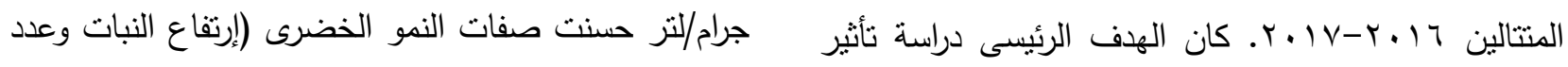

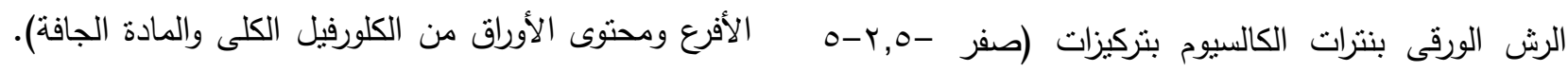

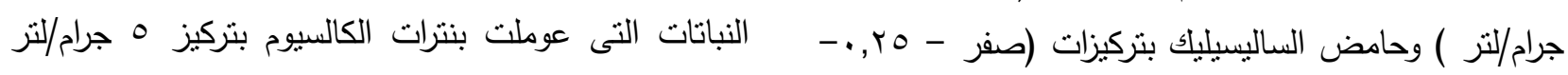

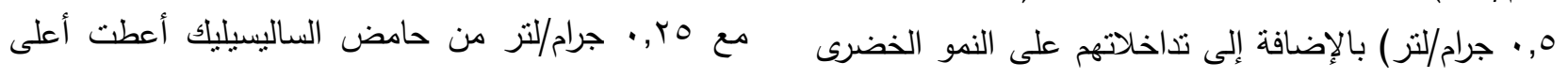

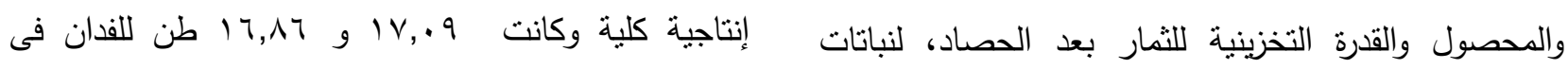

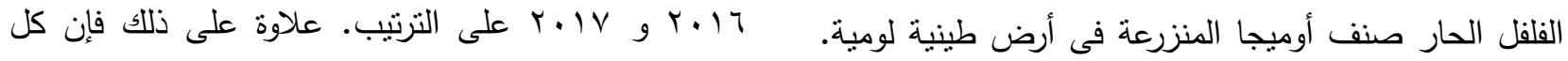
أستخدمت الثمار التى تم حصادها فى قياسات الجودة وقت معاملات نترات الكالسيوم وحامض الساليسيليك حسنت الحصاد وقياسات القدرة التخزينة بعد التخزين المبرد على بدرجة ملحوظة من جودة الثمار عند الحصاد وحافظت عليها

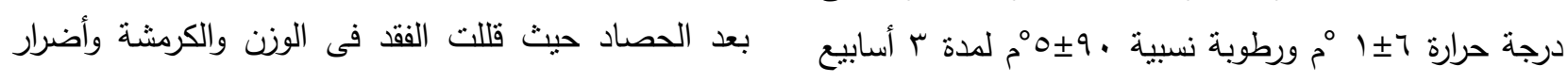
+ يومين على درجة حرارة الغرفة. أظهرت النتائج أن التبريد مقارنة بمعاملة الكنترول فى كلا موسمين الدراسة. 